\title{
CONCENTRAÇÃO E ACÚMULO DE NUTRIENTES E DETER- MINAÇÃO DO COEFICIENTE DE DIGESTIBILIDADE DA MATÉRIA SECA AO NIVEL DO RÚMEN DA Leucaena leucocephala (Lam.) DE WIT. CV. PERU EM FUNÇÃO DA IDADE
}

DENISE HELLÚ SILVA

Orientador: HENRIQUE PAULO HAAG

Dissertação apresentada à Escola Superior de Agricultura "Luiz de Queiroz", da Universidade de São Paulo, para obtenção do título de Mestre em Solos e Nutrição de

Plantas.

PIRACICABA

Estado de São Paulo - Brasil

Outubro, 1982 
A meus pais, RAUL e LEILA pela ajuda e incentivo

OFEREÇO

A meu marido LAURO, pelo carinho, compreensão e apoio e à minha filha LUCIANA 


\section{AGRADEC IMENTOS}

Ao Prof. Dr. Henrique Paulo Haag pelas sugestões e orien tação segura no desenvolvimento do presente trabalho.

Ao Prof. Dr. Keigo Minami pelas facilidades na instalação, condução e coleta do ensaio.

Ao Prof. Dr. Josē Mitidieri pela ajuda no levantamento bibliogrāfico.

A Eng - Agr - Maria José Valarini pela orientação e facilidades nos testes de digestibilidade.

Ao Instituto de Zootecnia da Secretaria da Agricultura do Estado de São Paulo, Nova Odessa-SP, na pessoa do Dr. Paulo B,Alcântara, pelo fornecimento das sementes e inoculantes.

A meus amigos Alcioneaurea e Humberto pela inestimável ajuda e incentivo.

Aos funcionārios do Departamento de Quîmica da Escola Superior de Agricultura "Luiz de Queiroz", Lücia, Lurdes, Mirtes e Francisco.

A Coordenadoria de Aperfeiçoamento do Pessoal de Ensino Superior - CAPES, pela bolsa concedida. 


\section{INDICE}

Pāgina

LISTA DE TABELAS $\ldots \ldots \ldots \ldots \ldots \ldots \ldots \ldots \ldots \ldots \ldots \ldots \ldots \ldots \ldots \ldots \ldots \ldots \ldots \ldots$

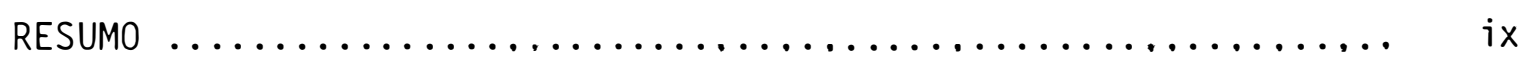

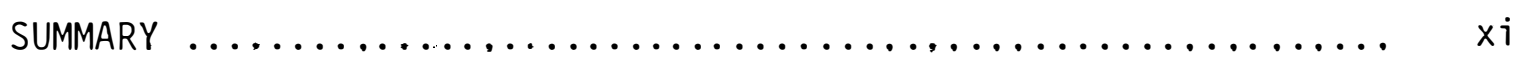

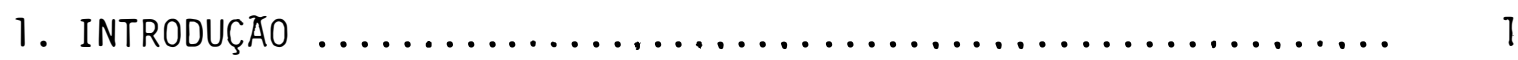

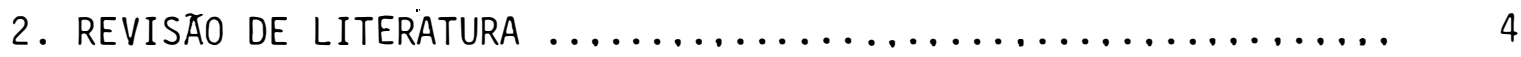

3. MATERIAIS E METODOS $\ldots \ldots \ldots \ldots \ldots \ldots \ldots \ldots \ldots \ldots \ldots \ldots \ldots \ldots \ldots \ldots \ldots \ldots$

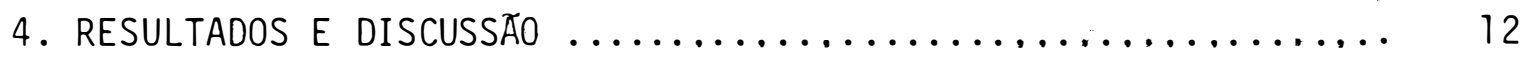

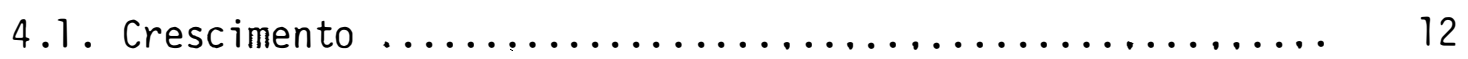

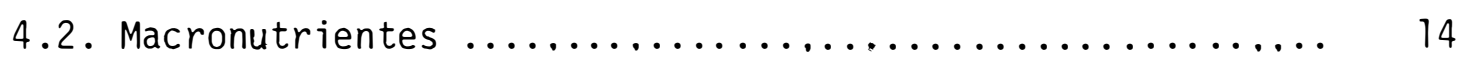

4.2.1. Nitrogênio $\ldots \ldots \ldots \ldots \ldots \ldots \ldots \ldots \ldots \ldots \ldots \ldots \ldots \ldots \ldots, 14$

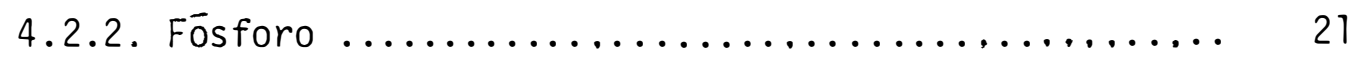

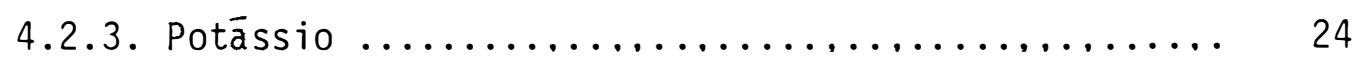

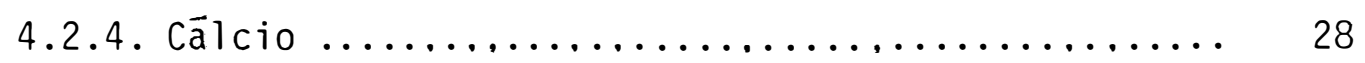

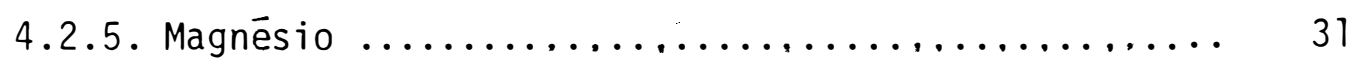

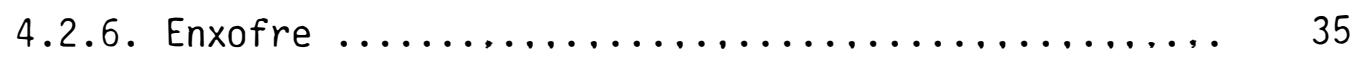

4.3. Micronutrientes $\ldots \ldots \ldots \ldots \ldots \ldots \ldots \ldots \ldots \ldots, 38$

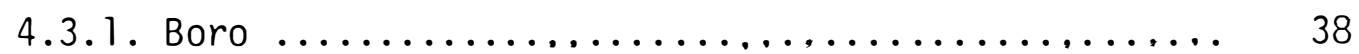

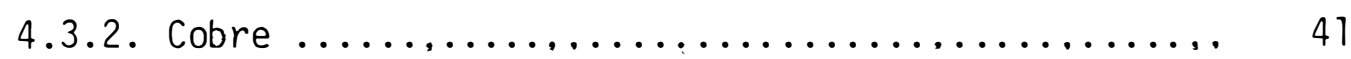

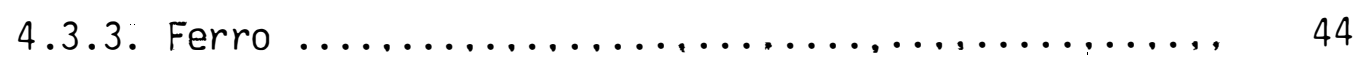

4.3.4. Manganês ............................ 47

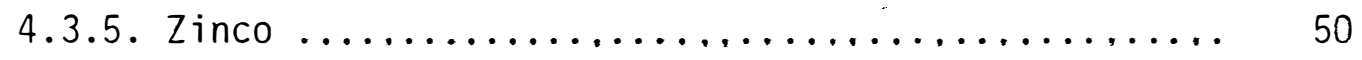

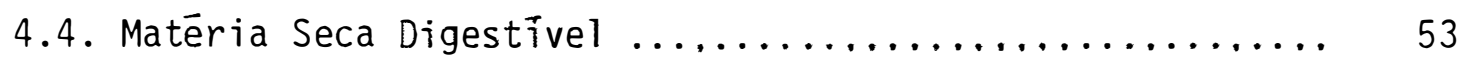

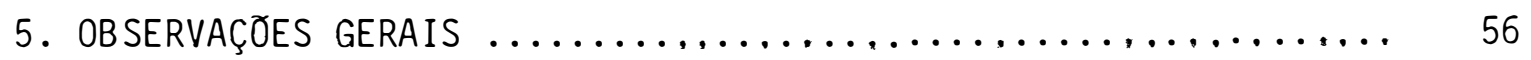

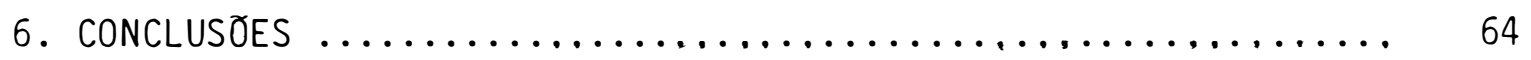

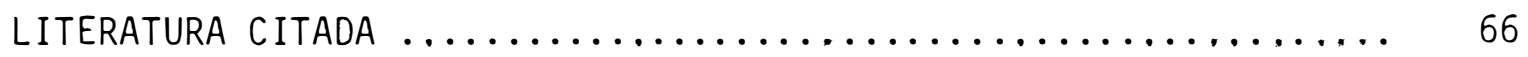




\section{LISTA DE TABELAS}

Tabela no

Pāgina

1 Produção de matēria seca em g/planta em função da idade e razão folha/caule ....................... 13

2 Concentração (\%) e acúmulo (g/planta) de nitrogênio nas partes da planta em função de diferentes

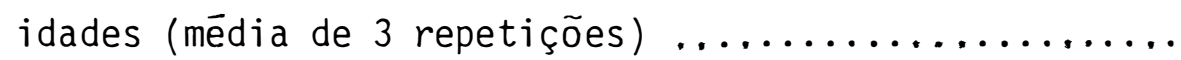

3 Relação do acúmulo de nutrientes pela forlha em diferentes idades $(60$ dias $=1) \ldots \ldots \ldots \ldots \ldots \ldots \ldots$

4. Relação do acúmulo de nutrientes pelo caule em diferentes idades $(60$ dias $=1) \ldots \ldots \ldots \ldots \ldots \ldots, 18$

5 Relação do acúmulo de nutrientes pela planta inteira em diferentes idades (60 dias $=1$ ) $\ldots \ldots \ldots \ldots \ldots$.

6 Equações de regressão e coeficientes de determinação $\left(R^{2}\right)$ do teor de nitrogēnio $(\% N=Y)$ em função da idade $(X)$ em partes da planta...

7 Concentração (\%) e acúmulo (g/planta) de fósforo nas partes da planta em função de diferentes ida-

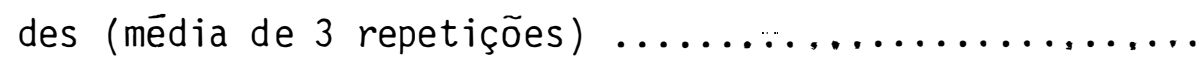

8 Equações de regressão, coeficientes de determinação $\left(R^{2}\right)$ e ponto de minimimo $(P m)$ do teor de fösforo $(\% P=Y)$ em função da idade $(X)$ em partes da plant 
9 Concentração (\%) e acúmulo (g/planta) de potāssio nas partes da planta em função de diferentes ida-

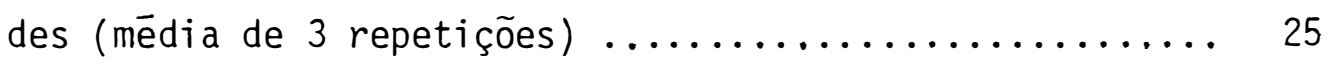

10 Equações de regressão e coeficientes de determinação $\left(R^{2}\right)$ do teor de potāssio $(\% K=Y)$ em função da idade $(X)$ em partes da planta ................ 26

11 Concentração (\%) e acümulo (g/planta) de cālcio nas partes da planta em função de diferentes idades (mëdia de 3 repetições) $\ldots \ldots \ldots \ldots \ldots \ldots \ldots \ldots \ldots . \ldots \ldots$

12 Equação de regressão, coeficiente de determinação $\left(R^{2}\right)$, ponto de máximo (PM), ponto de mīnimo (Pm) e ponto de inflexão (PI) do teor de cālcio(\% $\mathrm{Ca}=\mathrm{Y}$ ) em função da idade $(X)$ em partes da planta .......... 30

13 Concentração (\%) e acúmulo (g/planta) de magnēsio nas partes da planta em função de diferentes idades (mëdia de 3 repetições) $\ldots \ldots \ldots \ldots \ldots \ldots \ldots \ldots \ldots, 32$

14 Equações de regressão, coeficientes de determinação $\left(R^{2}\right)$, ponto de máximo $(P M)$, ponto de mínimo $(P m)$ e ponto de inflexão $(P I)$ do teor de magnésio $(\%$ Mg $=Y)$ em função da idade $(X)$ em partes da plan ta

15 Concentração (\%) e acúmulo (g/planta) de enxofre nas partes da planta em função de diferentes idades (mēdia de 3 repetições) $\ldots \ldots \ldots \ldots \ldots \ldots \ldots \ldots \ldots$ 
16 Equações de regressão, coeficientes de determinação $\left(R^{2}\right)$ e ponto de máximo (PM) do teor de enxofre $(\% S=Y)$ em função da idade $(X)$ em partes da planta .....

17 Concentração (ppm) e acúmulo (mg/planta) de boro nas partes da planta em função de diferentes idades (média de 3 repetições) $\ldots \ldots \ldots \ldots \ldots \ldots \ldots \ldots \ldots$.

18 Equação de regressão, coeficiente de determinação $\left(R^{2}\right)$ e ponto de minimo $(P m)$ do teor de boro $(p p m B=Y$ ) em função da idade $(X)$ em partes da planta .............

19 Concentração (ppm) e acúmulo (mg/planta) de cobre nas partes da planta em função de diferentes idades

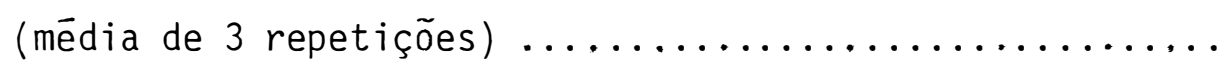

20 Equações de regressão, coeficientes de determinação $\left(R^{2}\right)$, ponto de máximo $(P M)$, ponto de mínimo $(P m)$ e ponto de inflexão (PI) do teor de cobre (ppm $\mathrm{Cu}=\mathrm{Y}$ ) em função da idade $(X)$ em partes da planta.........

21 Concentração (ppm) e acúmulo (mg/planta) de ferro nas partes da planta em função de diferentes idades

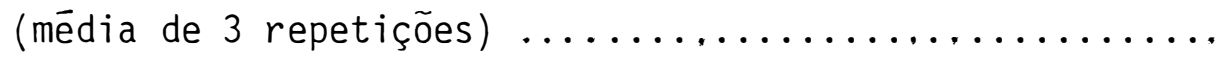

22 Equação de regressão, coeficiente de determinação $\left(R^{2}\right)$ e ponto de mínimo $(P m)$ do teor de ferro (ppm $\mathrm{Fe}=\mathrm{Y}$ ) em função da idade $(X)$ em partes da planta ......

23 Concentração (ppm) e acúmulo (mg/planta) de manganês nas partes da planta em função de diferentes idades (média de 3 repetições) $\ldots \ldots \ldots \ldots \ldots \ldots \ldots \ldots$. 
24 Equações de regressão e coeficientes de determinação $\left(R^{2}\right)$ do teor de manganês (ppm $M n=Y$ ) em função da

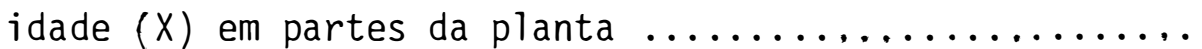

25 Concentração (ppm) e acúmulo (mg/planta) de zinco nas partes da planta em função de diferentes idades (mēdia de 3 repetições) .

26 Equações de regressão, coeficientes de determinação $\left(R^{2}\right)$, ponto de máximo (PM), ponto de mīnimo (Pm)e ponto de inflexão (PI) do teor de zinco (ppm $Z n=Y$ ) em função da idade $(X)$ em partes da planta ............

27 Matēria seca digestīvel (MSD \%) das folhas, em di-

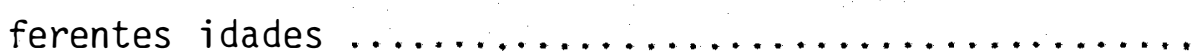

28 Equação de regressão, coeficiente de determinação $\left(R^{2}\right)$, ponto de máximo (PM), ponto de mínimo $(P m)$ e ponto de inflexão (PI) da matéria seca digestivel (MSD $\%=Y$ ) em função da idade $(X)$ das folhas .......... 54

29 Peso da matéria seca ( $t / h a)^{*}$ encontrados nas diferentes partes da planta em diferentes idades ......... 57

30 Macronutrientes ( $\mathrm{kg} / \mathrm{ha})$ * encontrados nas diferentes partes da planta em diferentes idades .............. 58

31 Micronutrientes ( $\mathrm{g} / \mathrm{ha}$ ) ${ }^{*}$ encontrados nas diferentes partes da planta em diferentes idades........... 
CONCENTRAÇÁO E ACOMULO dE NUTRIENTES E DETERMinAÇÃO DO COEFICIENTE DE DIGESTIBILIDADE DA MATERIA SECA AO NIVEL DO ROMEN DA Leucaena leucocephala (Lam.)
DE WIT. CV. PERU EM FUNÇAOO DA IDADE

Denise Hellu Silva

Orientador: Prof.Henrique Paulo Haag

RESUMO

As leguminosas tropicais constituem atualmente uma fonte de proteina de alta qualidade além de outras qualidades como produção de madeira no caso das arbustivas e como proteção contra erosão nas demais.

Sendo a leucena (Leucaena leucocephala (Lam.) de Wit cv. Peru) uma espécie bastante promissora para a pecuāria brasileira, foi con duzido um ensaio de campo com a finalidade de se conhecer o hábito alimentar dessa leguminosa. O ensaio foi instalado visando obter dados para anālise de crescimento, concentração e extração dos macronutrientes (N, $\mathrm{P}, \mathrm{K}, \mathrm{Ca}, \mathrm{Mg}$ e S) e micronutrientes ( $\mathrm{B}, \mathrm{Cu}, \mathrm{Fe}, \mathrm{Mn}$ e $\mathrm{Zn}$ ) e matéria seca digestivel das folhas "in vívo", em bovino, em função da idade da planta.

A partir dos dados obtidos constatou-se que:

a) A produção de matéria seca total é máxima aos 360 dias de idade e o maior incremento na produção de folhas, expresso em matéria seca, se dā dos 240 aos 360 dias. 
b) As concentrações de nitrogēnio, potássio e manganês diminuem nas folhas e caules com a idade da planta, ao passo que as concentrações de boro e ferro nas folhas e a de cálcio no caule não são afe tadas pela idade.

c) Aos 360 dias, época de produção máxima de matéria seca as folhas contēm em 535,46 g/planta: 16,26 g de nitrogènio, 0,61 $\mathrm{g}$ de fósforo, 10,65 g de potássio, 8,08 g de cālcio, 1,58 g de magnésio, 0,51 g de enxofre, $22 \mathrm{mg}$ de boro, $7 \mathrm{mg}$ de cobre, $204 \mathrm{mg}$ de ferro, $19 \mathrm{mg}$ de manganēs, $11 \mathrm{mg}$ de zinco.

d) Aos 360 dias, os caules contēm em 1783,33 g/planta: 15,82 $\mathrm{g}$ de nitrogēnio, 0,65 $\mathrm{g}$ de fósforo, 20,37 $\mathrm{g}$ de potássio, 7,01 $\mathrm{g}$ de cálcio, 0,44 g de magnésio, 1,06 g de enxofre, $20 \mathrm{mg}$ de boro, $13 \mathrm{mg}$ de cobre, $84 \mathrm{mg}$ de ferro, $10 \mathrm{mg}$ de manganēs, $36 \mathrm{mg}$ de zinco.

e) 0 acúmulo de nutrientes na planta aos 360 dias obedece a seguinte ordem para os macronutrientes: $\mathrm{N}>\mathrm{K}>\mathrm{Ca}>\mathrm{Mg}>\mathrm{S}>\mathrm{P}$, e para os micronutrientes: $\mathrm{Fe}>\mathrm{Zn}>\mathrm{B}>\mathrm{Mn}>\mathrm{Cu}$,

f) Aos 360 dias, a matēria seca digestĩvel das folhas ē $51,05 \%$. 


\section{CONCENTRATION AND ACCUMULATION OF NUTRIENTS AND DRY MATTER \\ DIGESTIB IL ITY IN THE RUMEN OF: Leucaena leucocephala (LAM.) \\ DE WIT CV. PERU DURING PERIOD OF ONE YEAR}

Candidate: Denise Hellu Silva Adviser: Prof. Henrique Paulo Haag

SUMMARY

The tropical leguminous are known as a high quality protein source and in some cases even as wood producers when concerning the arbustive leguminous.

The leucena (Leucaena leucocephala (Lam.) de Wit CV. Peru) was noticed as a very promissory specie to the brazilian cattle production, what leads to the layout of a field experiment in order to well knowits nutrient demands.

The experiment was made attempting to obtain data for analys is of growth, concentration and extraction of macranutrients (N, P, $\mathrm{K}, \mathrm{Ca}, \mathrm{Mg}, \mathrm{S}$ ) and micronutrients (B, Cu, Fe, $\mathrm{Mn}, \mathrm{Zn}$ ) and the dry matter digestibility in vivo for the leaves related to the plant age.

From the obtained data was possible to verify that:

The whole dry matter production is highest when the plant was 360 days old. The largest increase in the leaves production in dry matter was observed from 240 days up to 360 days. 
The $N, P$ and $M n$ concentrations decrease in leaves and stem along the plant live.

On the other hand, the age of the plant did not affected neither the $\mathrm{B}$ and $\mathrm{Fe}$ concentrations in the leaves nor the $\mathrm{Ca}$ concentration in the stem.

When the plants were 360 days old corresponding to the highest dry matter production period, were observed the following contents in the leaves and stem:

\begin{tabular}{ccc} 
Element & leaves $(535.46 \mathrm{~g} / \mathrm{plant})$ & Stem $(1,783,33 \mathrm{~g} / \mathrm{plant})$ \\
\hline $\mathrm{N}$ & $16.26 \mathrm{~g}$ & $15.82 \mathrm{~g}$ \\
$\mathrm{P}$ & 0.61 & 0.65 \\
$\mathrm{~K}$ & 10.65 & 20.37 \\
$\mathrm{Ca}$ & 8.08 & 7.01 \\
$\mathrm{Mg}$ & 1.58 & 0.44 \\
$\mathrm{~S}$ & 0.51 & 1.06 \\
$\mathrm{~B}$ & $22 \mathrm{mg}$ & $20 \mathrm{mg}$ \\
$\mathrm{Cu}$ & 7 & 13 \\
$\mathrm{Fe}$ & 204 & 84 \\
$\mathrm{Mn}$ & 19 & 10 \\
$\mathrm{Zn}$ & 11 & 36 \\
\hline
\end{tabular}

Plants with 360 days also noticed that the nutrient accumulations shown itself in the following order:

$$
\begin{array}{ll}
\mathrm{N}>\mathrm{K}>\mathrm{Ca}>\mathrm{Mg}>\mathrm{S}>\mathrm{P} & \text { (macronutrients) } \\
\mathrm{Fe}>\mathrm{Zn}>\mathrm{B}>\mathrm{Mn}>\mathrm{Cu} & \text { (micronutrients) }
\end{array}
$$

The digestibility of the dry matter in leaves is in the level of $51,05 \%$, in 360 days old plant. 
1. INTRODUÇÃO

As gramineas, atē cerca de duas décadas atrās, vinham re cebendo maior atenção tanto dos pecuaristas como dos pesquisadores, em todas as partes do mundo. Entretanto, com o aumento substancial no preço dos fertilizantes nitrogenados, aliado a deficiēncia de proteinas, principalmente nos tröpicos (OAKES e SKOV, 1967; JONES, 1979), que 1 imi tam sobremaneira a produção animal, a tendēncia atual é uma maior aten ção para com as leguminosas.

A utilização de leguminosas que forneçam nitrogênio ao sistema e produzam forragem com elevado teor de proteina, mesmo na estação seca, indica ser uma solução bastante promissora àmanutenção do gado.

Pesquisas com leguminosas estão sendo feitas com grande intensidade, destacando-se os levantamentos realizados pela Academia Nacional de Ciēncias dos Estados Unidos, as pesquisas conduzidas pela Divisão de Culturas e Pastagens Tropicais doCSIRO* - Austrālia e pela CIAT**.

\footnotetext{
* Commonwealth Scientific and Industrial Research Organization.

** Centro Internacional de Agricultura Tropical, Cali, Colómbia.
} 
Grande empenho por parte dessas instituições estão voltados à uma leguminosa forrageira - a Leucaena leucocephala - com grande possibilidade de vir a ser empregada num futuro prōximo com sucesso no Brasil. Recentemente um pesquisador (OAKES, 1982) do laboratōrio de botânica do Departamento de Agricultura dos Estados Unidos, apresentou um levantamento bibliográfico referente a essa leguminosa contendo 1308 referēncias das quais somente 9 são referentes especificamente à nutrição minera 1.

A Leucaena leucocephala (Lam.) de Wit è uma leguminosa pertencente a subfamîlia Mimosoideae e à tribo Eumimoseas (ALCĀNTARA et alii, 1979), sendo nativa do México, de onde se espalhou para as ilhas do Caribe, India, Nova Guiné, Tailāndia, Malaia, Indochina Francesa, Africa e Amēricas tropicais (Hill, 1971, Dijkman e Farinas, citados por VILELA, 1976).

De acordo com ROCHA et alii (1971), a leucena seria uma das leguminosas tropicais de maior potencial para uso em pastagens. Tal afirmação deriva do fato que essa leguminosa parece conter em suas folhas e brotos alguns "fatores de crescimento" (JONES, 1979), que a tor na superior em relação à outras leguminosas, proporcionando aos animais produtividades mais altas. Além disso sua tolerāncia à seca (HUTTON, 1970), atribuido ao fato de ser uma leguminosa arbustiva, e seu alto teor de proteina de boa qualidade mesmo em condições climāticas desfavorāveis, faz com que ela ofereça grandes perspectivas de se estabelecer com sucesso. 
HUTTON (1979) afirma estar sendo desenvolvido no Brasil grande interesse por essa leguminosa arbustiva, que vem se desenvolvendo bastante satisfatoriamente em āreas limitadas do cerrado e em algumas do nordeste. Entretanto, JONES (1979) destaca ser necessārio ainda estudos suplementares para a real avaliação do potencial da leucena como forrageira, apontando claramente suas vantagens, a fim de que se decida um esforço para sua formação e manutenção.

0 uso da leucena tem sido retardado por causa de um aminoācido, a mimosina, que é um composto tōxico aos ruminantes a partir de uma certa proporção na dieta. A fim de eliminar esse inconveniente, estão sendo desenvolvidos cultivares com baixo teor de mimosina (CIAT, $1981)$.

0 presente estudo visa:

- Analisar o crescimento da Leucaena leucocephala (Lam.) de Wit.

- Determinar a concentração de macro e micronutrientes, em função da idade.

- Determinar a extração de macronutrientes e micronutrientes (B, Fe, Cu, Mn, Zn) em função da idade.

- Determinar a digestibilidade da matéria seca in vivo em função da idade. 


\section{REVISÃO DE LITERATURA}

0 crescimento normalmente é avaliado pelos pesquisadores atravēs do peso da matēria seca em se tratando de leguminosa forrageira (NEME e LOVADINI, 1967; JONES e QUAGLIATO, 1970; WERNER e MATTOS, 1972). A literatura no que se refere à produção difere consideravelmen te de um autor para outro. Isso poderia ser explicado, segundo a NATIONAL ACADEMY OF SCIENCES (1977) pelo fato da produção de forragem ser influenciada pela variedade, condições climáticas e ambientais. Tanto è que FARINAS (1953) no Havaî conseguiu obter 48 t/ha/ano de matēria se ca, enquanto que PESSANHA (1956) sō obteve 12 t/ha/ano em Angola.

Dos cultivares agrupados por HUTTON e GRAY (1959) e ALCĀNTARA e BUFARAH (1979), o mais produtivo e o que possui mais proteína e o cultivar Peru (Hutton e Bonner, citados por HUTTON, 1970).

MENDOZA e JAVIER (1980) determinaram a produção de matéria seca de Leucaena leucocephala cv. Peru, nas Filipinas, em uma cultura estabelecida por 6 meses, cortada a cada 60 dias, durante 12 meses. Obtiveram uma média de produção de 22,27 t/ha/ano. 
Em levantamentos feitos pela NATIONAL ACADEMY OF SCIENCES (1977), foi constatado que geralmente a produção de matéria secá está entre 2-20 t/ha.

A leucena é tolerante a baixos niveis de fertilidade do solo (HILL, 1971; ALCĀNTARA e BUFARAH, 1979; LIMA et alii, 1981), embora um bom rendimento só seja conseguido em solos férteis (NATIONAL ACADEMY OF SCIENCES,1977). Essa mesma fonte afirma que a fertilização do solo parece ser essencial para a leucena que exige um balanço nutricional adequado.

DAMSEAUX (1957) estudou três leguminosas forrageiras no Congo Belga: Medicago sativa, Stylosanthes gracilis e Leucaena glauca*, sendo que as leguminosas mostraram-se ricas em Ca, pobres em $P$, a leucena mostrou maior concentração em K (TAKAHASHI e RIPPERTON, 1949). Já ROCHA et alii (1971) no Brasil afirmaram que o $K$ não seria fator limitante da introdução de uma leguminosa em nossas pastagens, podendo ser aplicado depois que outras deficiencias fossem corrigidas.

A maioria dos solos brasileiros são pobres em $P$, assim como os da Austrāitia (RUSSELL, 1978). Desse modo se pode prever sua importāncia para a formação e adequado desenvolvimento das leguminosas forrageiras, a tal ponto de ROCHA et alii (1971) e WERNER (1977) afirmarem ser esse elemento o principal nutriente às plantas dessa famîlia. NORRIS (1965), NORRIS (1967) e ISWARAN et alii (1970) afirmam que leguminosas tropicais toleram melhor solos deficientes em $\mathrm{Ca}$ que

\footnotetext{
* Denominação da Leucaena leucocephala antes de 1960.
} 
leguminosas temperadas, e são mais sensiveis a deficiência de nutrientes que as gramineas (HUTTON, 1970; RUSSELL, 1978). A primeira afirmação vem a ser confirmada por ANDREW e NORRIS (1961) que obtiveram dados onde calcularam que as leguminosas tropicais extraem em média 24 vezes mais Ca que as temperadas.

OAKES e SKOV (1967) consideram a leucena uma das poucas leguminosas tropicais adaptada a solos com alto nivel de Ca.

Em um estudo da composição do farelo de folhas de leucena D'MELLO e THOMAS (1978) no Malawi encontraram teores da ordem dos ci tados abaixo:

\begin{tabular}{lcc}
\hline \multirow{2}{*}{ Elemento } & \multicolumn{3}{c}{ Teor (mat. seca) } \\
\cline { 2 - 3 } Nitrogēnio & 38,4 & 3,84 \\
Fósforo & 2,3 & 0,23 \\
Cálcio & 24,7 & 2,47 \\
Södio & 0,1 & 0,01 \\
Potássio & 15,3 & 1,53 \\
Magnésio & 3,6 & 0,36 \\
\hline
\end{tabular}

Outros pesquisadores, HAAG e MITIDIERI (1980) no Brasil, objetivando a obtenção de um quadro sintomatológico da caréncia de macronutrientes e de $B$, utilizando-se de solução nutritiva obtiveram para plantas normais os seguintes teores dos elementos nas folhas: 
$\mathrm{N} \%-3,51 ; \mathrm{P} \%-0,4 ; \mathrm{K} \%-2,75 ; \mathrm{Ca} \%-1,11 ; \mathrm{Mg} \%-0,42 ; \mathrm{S} \%-0,22$ e Bppm - 127, e as com sintomas: N\% - 2,79; P\% - 0,11; K\% - 1,33; Ca\%-0,41; $\mathrm{Mg} \%-0,18 ; \mathrm{S} \%-0,11$ e Bppm - 25 .

ROSAS, QUINTERO e GOMES (1980) no Panamā, em amostras obtidas de plantas com diferentes alturas encontraram:

Altura (m)

\begin{tabular}{llccc}
\hline & 0,5 & 1,0 & 1,5 & $2,0 \ldots 2,5$ \\
\hline $\mathrm{Ca}(\%)$ & $: 2,49 ; 2,15 ; 2,02 ; 2,44$ e 2,00 \\
$\mathrm{P}(\%) \quad: 0,09 ; 0,13 ; 0,10 ; 0,09$ e 0,07 \\
$\mathrm{Cu}(\mathrm{mg} / \mathrm{Kg}): 5,0 ; 8,0 ; 4,0 ; 6,0$ e 4,0 \\
$\mathrm{Fe}(\mathrm{mg} / \mathrm{Kg}): 123 ; 135 ; 138 ; 153$ e 168 \\
\hline
\end{tabular}

A concentração de Ca na leucena parece variar consideravelmente em função do local (JONES, 1979). Em dịversos tipos de solos australianos a concentração de Ca raramente excede $1 \%$ da matéria seca, enquanto que nomaterial produzido na India e no Malawi são relatados valores de mais de $2 \%$ de Ca nas folhas de leucena.

ADENEYE (1981) na Nigéria, apresentou a composição mineral da matéria seca de folhas de leucena: Ca\% - 2,8; $\mathrm{P} \%-0,26 ; \mathrm{Mg} \%-0,37$; $\mathrm{K} \%-1,78 ; \mathrm{Na} \%-0,21$ e $\mathrm{Fe} \%-0,12$.

A NATIONAL ACADEMY OF SCIENCES (1977) rela.tou que no Havai, um hectare de folhas de leucena obtidas de arbustos com um ano de idade continham $44 \mathrm{Kg}$ de $\mathrm{P}$ e $187 \mathrm{Kg}$ de $\mathrm{K}$. Essa mesma fonte apresenta os nutrientes presentes em folhas secas de leucena (incluindo ramos finos) 
como sendo:

\begin{tabular}{cc}
\hline Elemento & $\%$ \\
\hline$N$ & $2,2-4,3$ \\
$P$ & $0,2-0,4$ \\
$K$ & $1,3-4,0$ \\
$\mathrm{Ca}$ & $0,8-2,0$ \\
$\mathrm{Mg}$ & $0,4-1,0$ \\
\hline
\end{tabular}

Analisando pontas de brotos que tinham aproximadamente $1 \mathrm{~m}$ de comprimento (JONES, 1979), na Austrāitia, obteve as seguintes concentrações de nutrientes em Leucaena leucocephala cv. Peru: N\%-4,8; $\mathrm{P} \%-0,38 ; \mathrm{S} \%-0,33 ; \mathrm{Ca} \%-1,18 ; \mathrm{Mg} \%-0,41 ; \mathrm{Na} \%-0,07 ; \mathrm{K} \%-1,7 ; \mathrm{Cu} \mathrm{ppm}-9$; Zn ppm- 44 .

LEE (1981) em Taiwan determinou a composição de nutrientes na planta inteira de L. leucocephala cv. Hawai obtendo os seguintes dados: $\mathrm{Ca} \%-0,46 ; \mathrm{P} \%-0,07 ; \mathrm{Mg} \%-0,19 ; \mathrm{Mnppm}-23,00 ; \mathrm{Fe}$ ppm - 150,00; Zn ppm - 20,00. 


\section{MATERIAIS E METODOS}

0 experimento foi realizado no campo experimental perten cente ao Departamento de Agricultura e Horticultura da Escola Superior de Agricultura "Luiz de Queiroz" - USP, Piracicaba, São Paulo. A localidade tem as coordenadas geogräficas: Latitude $22^{\circ} 41^{\prime} 31^{\prime \prime}$ Sul e Longitude $47^{\circ} 38^{\prime} 07^{\prime \prime}$ Oeste; altitude $540 \mathrm{~m}$ (Instituto Brasileiro de Geografia e Estatistica, : 1957).

0 solo onde foi instalado o experimento é um LatossoloVermelho Escuro-Orto, sērie "Luiz de Queiroz" (RANZANI et alii, 1966), e vem sendo cultivado a muitos anos com plantio de hortaliças. A anālise química desse solo apresenta os seguintes parāmetros:

\begin{tabular}{|c|c|c|c|c|c|}
\hline \multirow{2}{*}{$\stackrel{\mathrm{pH}}{\left(1: 2 \mathrm{H}_{2} \mathrm{O}\right)}$} & \multirow{2}{*}{$\mathrm{C} \%$} & \multicolumn{4}{|c|}{ Teor trocāvel em e.mg/100g TFSA } \\
\hline & & $\mathrm{PO}_{4}^{-3 *}$ & $k^{+}$ & $\mathrm{Ca}^{++}+\mathrm{Mg}^{++}$ & $\mathrm{AT}^{+3}$ \\
\hline 5,9 & 3,7 & 1,0 & 0,45 & 13,60 & 0,0 \\
\hline
\end{tabular}


Segundo o sistema de Köeppen o clima da região recebe a classificação de Cwa-tropical ümido com inverno seco. A temperatura do més mais quente è superior a $22^{\circ} \mathrm{C}$ e a do mês mais frio inferior a $18^{\circ} \mathrm{C}$ (SETZER, 1946).

0 tratamento para quebra de dorméncia foi feito merguThando-se as sementes em $\mathrm{H}_{2} \mathrm{SO}_{4}$ concentrado por 3 minutos, de: acordo com Akamine, citado por HILL (1971). Em seguida as mesmas foram inoculadas com inoculantes específicos usando as estirpes: TAL $-82+$ + CIAT - 1967 + CB - 81. Para cada Kg de semente foram utilizados 3,6g de inōculo e 4,og de adesivo, sendo em seguida postas em tambor giratōrio onde permaneceram em rotação por 24 horas (VALARINI, 1982)*. A semeadura procedeu-se em 17/02/1981**.

Aos 30 dias após a germinação foi feito o primeiro desbaste, deixando uma planta a cada $20 \mathrm{~cm}$, e espaçamento entre linhas de Im, quando foi feita também uma adubação em cobertura. Esta foi feita aos 30,40 e 60 dias utilizando $40 \mathrm{~g}$ de sulfato de amonio por metro linear. Um segundo desbaste foi feito aos 50 dias apōs a semeadura, deixando uma distància entre plantas de $50 \mathrm{~cm}$.

A irrigação foj feita no sulco, semanalmente, quando necessäria.

As coletas foram realizadas a cada 60 dias apös a semeadura. As plantas, em nümero de trēs, foram cortadas rente ao solo,

* MARIA J. VAlarini. Instituto de Zootecnia da Secretaria da Agricultura do Estado de São Paulo, Nova Odessa-SP, Comunicação pessoal.

**Sementes cedidas pela Seção de Plantas Forrageiras do Instituto de Zootecnia da Secretaria da Agricultura do Estado de São Paulo, Nova Odessa-SP. 
separadas em follhas e caules, lavadas com água destilada (SARRUGE e HAAG, 1974) e postas a secar em estufa de circulação forçada de ar a $80^{\circ} \mathrm{C}$. A matéria seca foi analisada para N, P, K, Ca, Mg, S, B, Cu, Fe, Mn e $\mathrm{Zn}$, segundo recomendações contidas nos autores citados acima.

Cinco gramas de folhas secas e moidas de diferentes idades foram colocadas em sacos de "nylon" de $10 \times 15 \mathrm{~cm}$ com malha de 100 "mesh" e utilizadas para teste de digestibilidade in vivo. Os sacos foram introduzidos no rúmen do animal ai permanecendo por 72 horas. Apōs esse período foram retirados, lavados em água corrente e postos a secar a $105^{\circ} \mathrm{C}$ durante 24 horas. 0 peso inicial da amostra foi corrigido para matéria seca a $105^{\circ} \mathrm{C}$. Essa diferença seria a matéria seca desaparecida, usada para a estimatịva da digestibilidade.

0 del ineamento utilizado foi inteiramente casualizado com 3 repetições. Anālise de variāncia da concentração e acúmulo de nutrien tes nas folhas e caules, do acúmulo de matéria seca e da concentração de matēria seca digestivel nas folhas. Anālise de regressão para concentrações de nutrientes, nas folhas e caules e matēria seca digestīvel nas folhas em função de épocas e os respectivos pontos de máximo, mỉnimo e inflexão. A curva escolhida foi aquela de grau mais elevado, significativo. 


\section{RESULTADOS E DISCUSSAOO}

\subsection{Crescimento}

Pelos dados expostos na tabela 1 verificam-se diferenças significativas para folhas, caules e planta: inteira em função da idade da planta. A proporção de matéria seca das folhas foi superior a do caule atē 180 dias, a partir daí essa tendência se inverteu o que mostra a variação dessa relação com o envelhecimento da planta. Esses dados são importantes para determinar o tipo de material que serā oferecido ao animal em determinada época.

Constatou-se um grande aumento do peso da matéria seca do caule entre 300 e 360 dias. A lignificação do material parece ser a explicação para tal fato. A diminuição da digestibilidade aos 360 dias $(51,05 \%)$, presente na tabela 27 parece indicar ser ocorrido o mesmo fenômeno nas folhas. Segundo YEO (1977) o coeficiente de digestibilidade da matēria seca ē afetado principalmente pelo aumento de lignina nas paredes celulares com o envelhecimento da planta. CRAMPTON e MAYNARD(1938) 


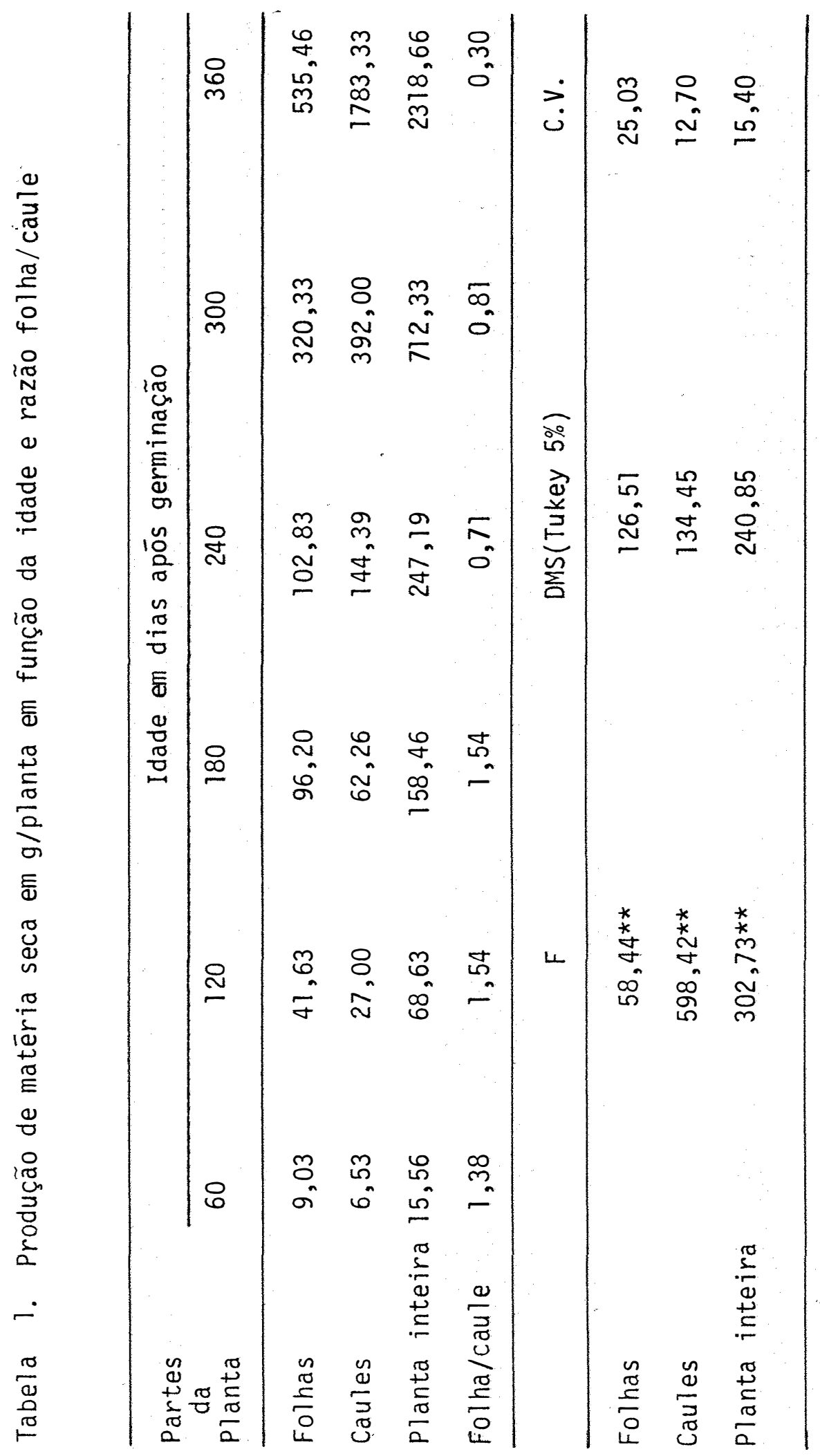


afirmam que a lignificação altera o valor nutritivo da planta e è consequēncia da maturidade.

MENDOZA e JAVIER (1980) obtiveram uma produção média de L. Leucocephala cv. Peru de 22,27 ton. de matéria seca/ha/ano, enquanto que 0 presente trabalho apresentou uma produção estimada de 46,37 t/ha/ ano (tabela 29). Desse valor encontrado para leucena, as folhas contribuiram com 10,70 t/ha/ano e o caule com 35,66 t/ha/ano (tabela 29). Apesar de se tratar de um arbusto, essa leguminosa é bastante aceita pe10 gado, que se alimenta das folhas e talos jovens com diāmetro de 5 a $6 \mathrm{~mm}$. Jā os talos mais grossos são menos aceitos e nutritivos que as fo Thas e talos jovens (JONES, 1979).

\subsection{Macronutrientes.}

4.2.1. Nitrogēnio

Os teores de nitrogēnio nas folhas e caules acham-se presentes na tabela 2 e mostraram correlação com a idade. Ambos mostraram que os teores diminuiram linearmente com a idade segundo equações de 10 grau expostas na tabela 6. Os valores limites calculados entre 60 e 360 dias variaram de $5,00 \%$ a $2,96 \%$ para as folhas e $2,14 \%$ a $0,92 \%$ para os caules. GOMIDE (1976) atribui esse decréscimo ao efeito de diluição do nitrogēnio na matéria seca (decréscimo da concentração de nitrogēnio em função do aumento da matéria seca), diminuição da capacidade da planta em absorver os nutrientes do solo e variação na relação caule-folha. 
HAAG e MITIDIERI (1980) obtiveram em folhas de plantas sem deficiência $3,51 \%$ de $\mathrm{N}$ e em plantas com sintomas de deficiēncia $2,79 \%$. Entretanto a NATIONAL ACADEMY OF SCIENCES (1977) relata uma ampla gama de valores que vão de $2,2 \%$ a $4,3 \%$ de $\mathrm{N}$ em folhas de leucena.

GOMIDE (1976) cita dados de teores de nitrogênio em centrosema (Centrosema pubescens), siratro (Phaseollus macropitillium) e soja perene (Glycine javanica), consorciados com capim jaraguá (Hyparhenia rufa) como sendo $2,50 \%, 2,24 \%$ e $2,45 \%$ de $N$ respectivamente na matéria seca.

OLIVEIRA et alii (1978) não encontraram nos caules de soja perene (Glycine wightii Willd.) e siratro(Macroptiliumatropurpureum cv. 'siratro') correlação do teor de nitrogênio com a idade e no caule de centrosema (Centrosema pubescens Benth) os teores do nutriente aumentaram com a idade. As folhas dessas mesmas espëcies variaram seus teores de nitrogênio com a idade.

0 acúmulo de nitrogênio pela folha, caule e planta inteira encontra-se respectivamente nas tabelas 3,4 e 5 . Observa-se que 0 acúmulo pela folha foi 36,9 vezes maior no ūltimo corte em relação ao primeiro, no caule o aumento foi de 158,2 vezes e na planta inteira 58,9 vezes. 


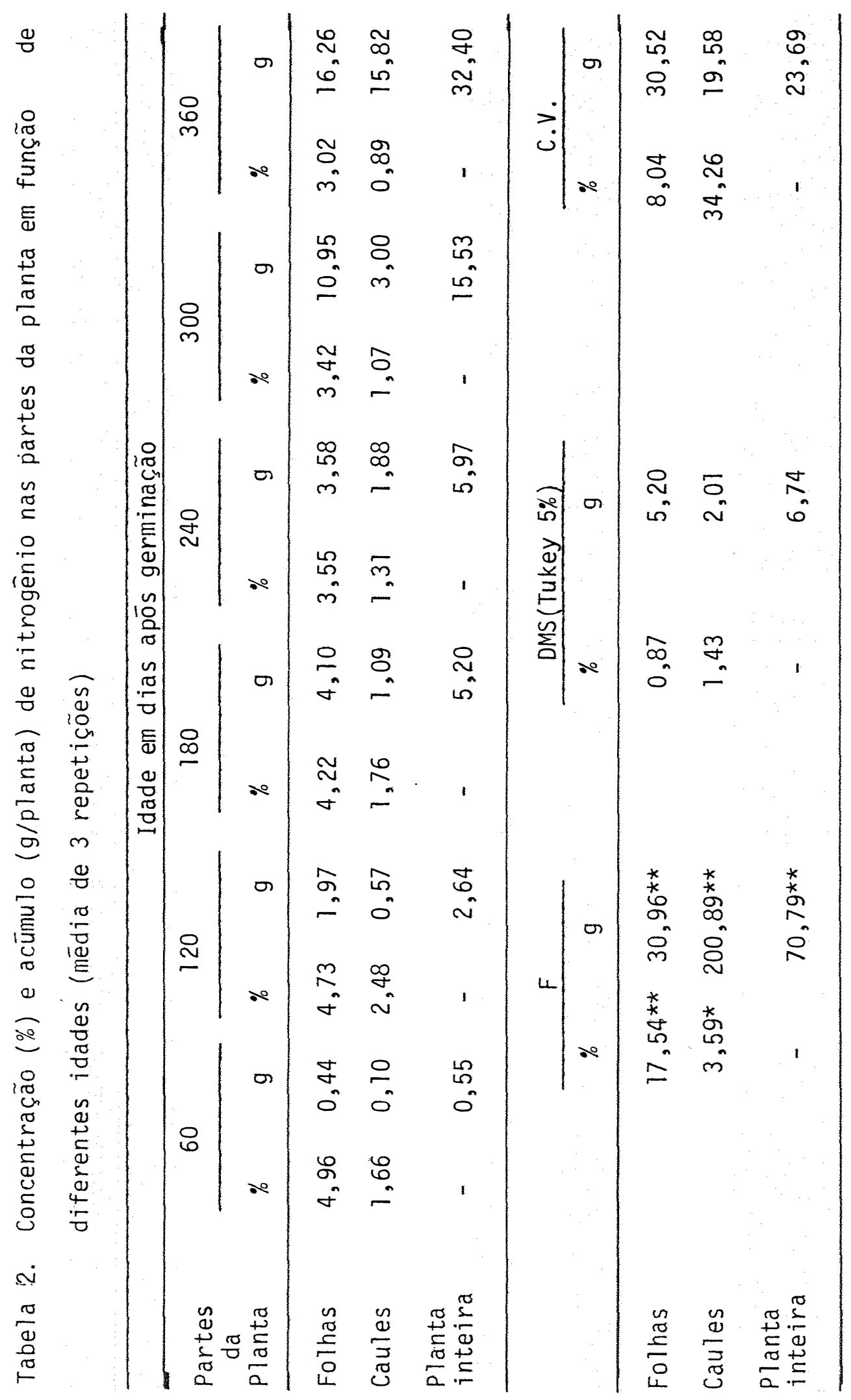




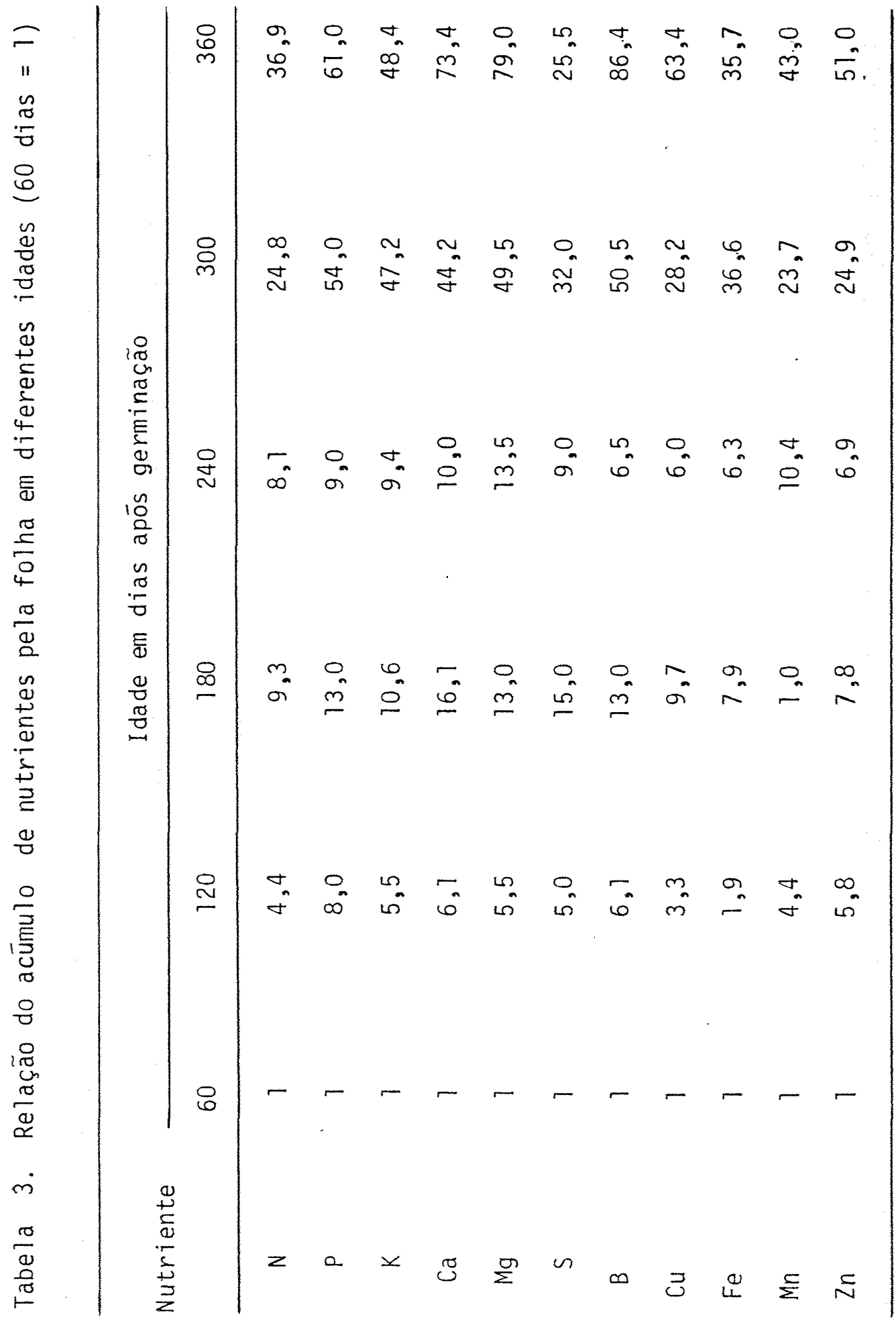




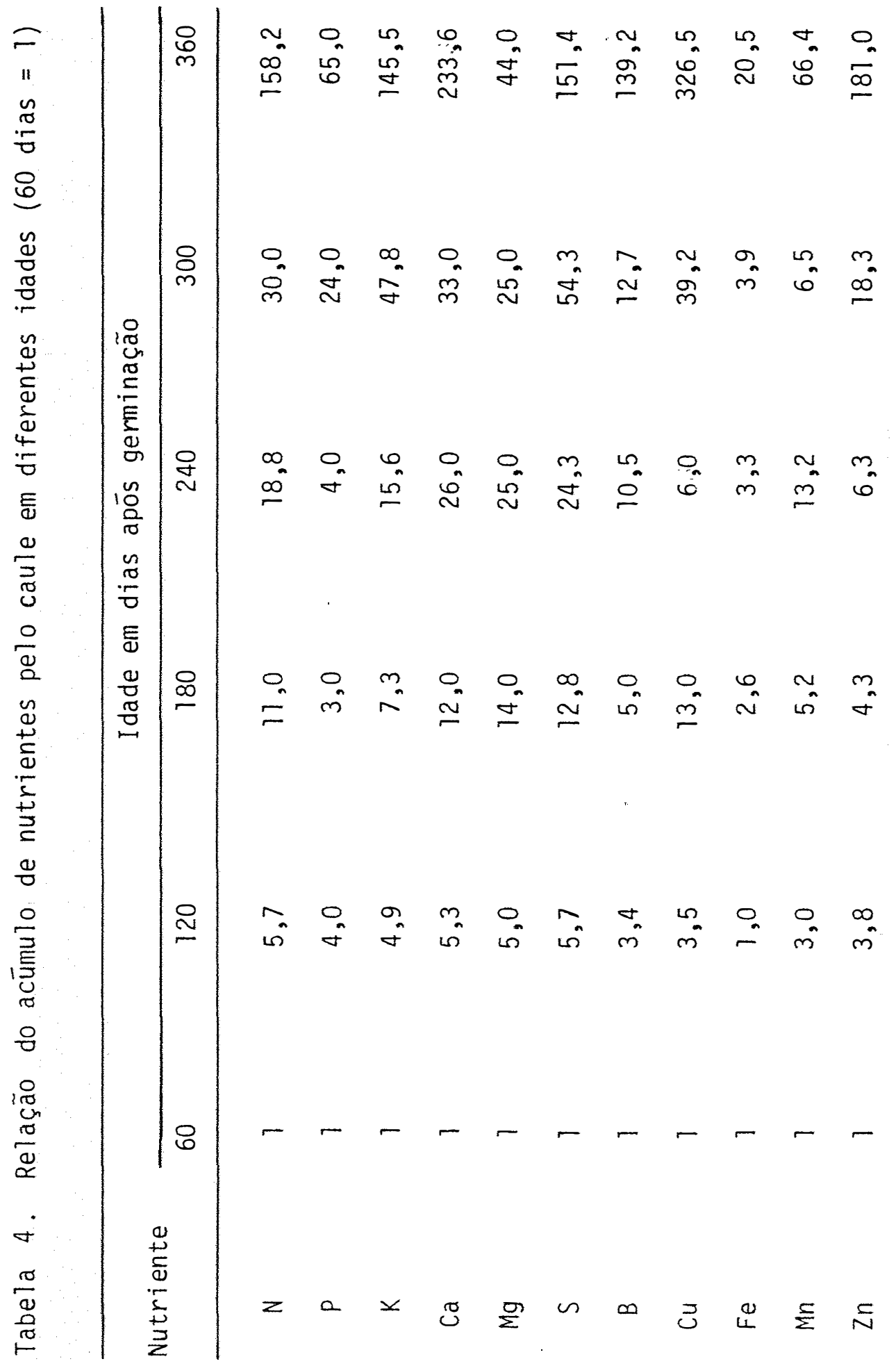




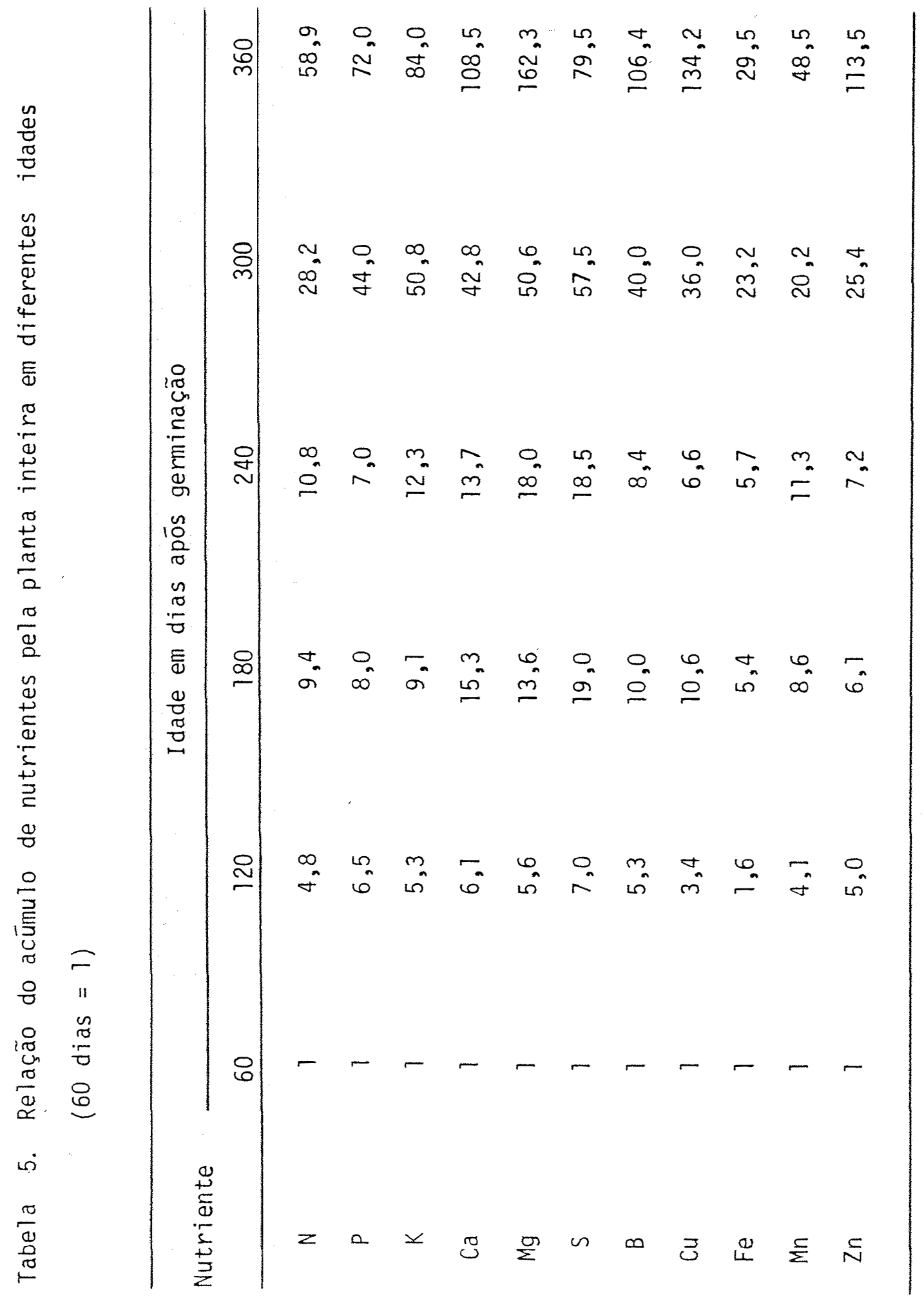




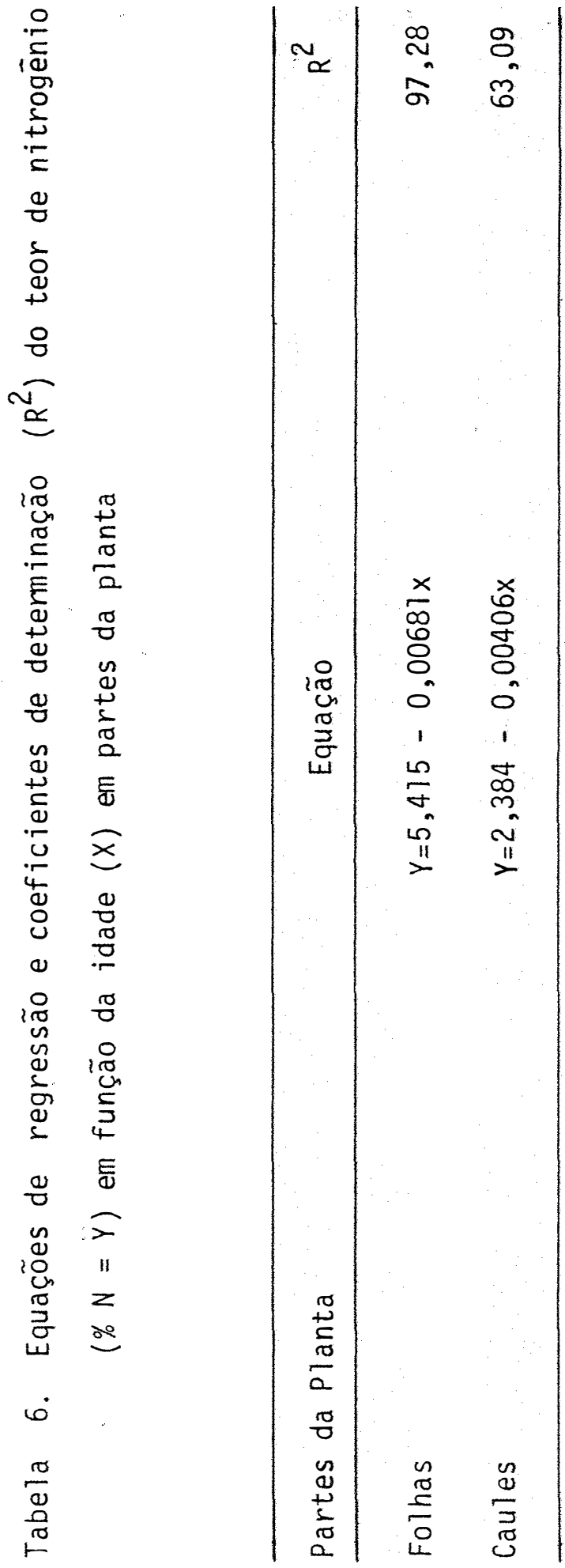




\subsubsection{Fósforo}

Os teores de fösforo nas folhas e caules encontram-se na tabela 7 e mostraram correlação com a idade traduzidos por uma equação de regressão quadrätica e uma cúbica presentes na tabela 8 .

Nas folhas os valores observados variaram de $0,27 \%$ aos 60 dias atē $0,11 \%$ aos 360 dias. Nos caules essa concentração variou de $0,25 \%$ a $0,03 \%$ no mesmo periodo. OLIVEIRA et alii (1978) encontraram valores da concentração de $P$ na parte aérea da centrosema (Centrosema pubescens Benth) variando de $0,25 \%$ a $0,35 \%$.

Os dados relatados para as folhas estão abaixo dos apresentados pela NATIONAL ACADEMY OF SCIENCES (1977) que apresenta teores de $P$ em folhas secas de leucena variando de $0,2 \%$ a $0,4 \%$, que coincidem com HAAG e MITIDIERI (1980) que encontraram 0,40\% de $P$ em folhas provenientes de plantas sem deficiência. Esses mesmos autores encontraram 0,11 de P nas folhas de plantas com sintomas de deficiēncia, valor igual ao encontrado no presente trabalho em folhas de plantas com 360 dias de idade. Valores concordantes encontraram D'MELLO e THOMAS (1978) e ADENEYE (1981) de $0,23 \%$ e $0,26 \%$ de $P$ respectivamente em folhas de leucena,

GOMIDE (1976) cita dados de teores de fósforo em centrosema (Centrosema pubescens), siratro (Phaseollus Macroptilium) e soja perene (Glycine javanica) consorciados com capim-jaraguā (Hyparhenia rufa como sendo $0,10 \%, 0,09 \%$ e $0,10 \%$ de $P$ respectivamente na matéria seca. 


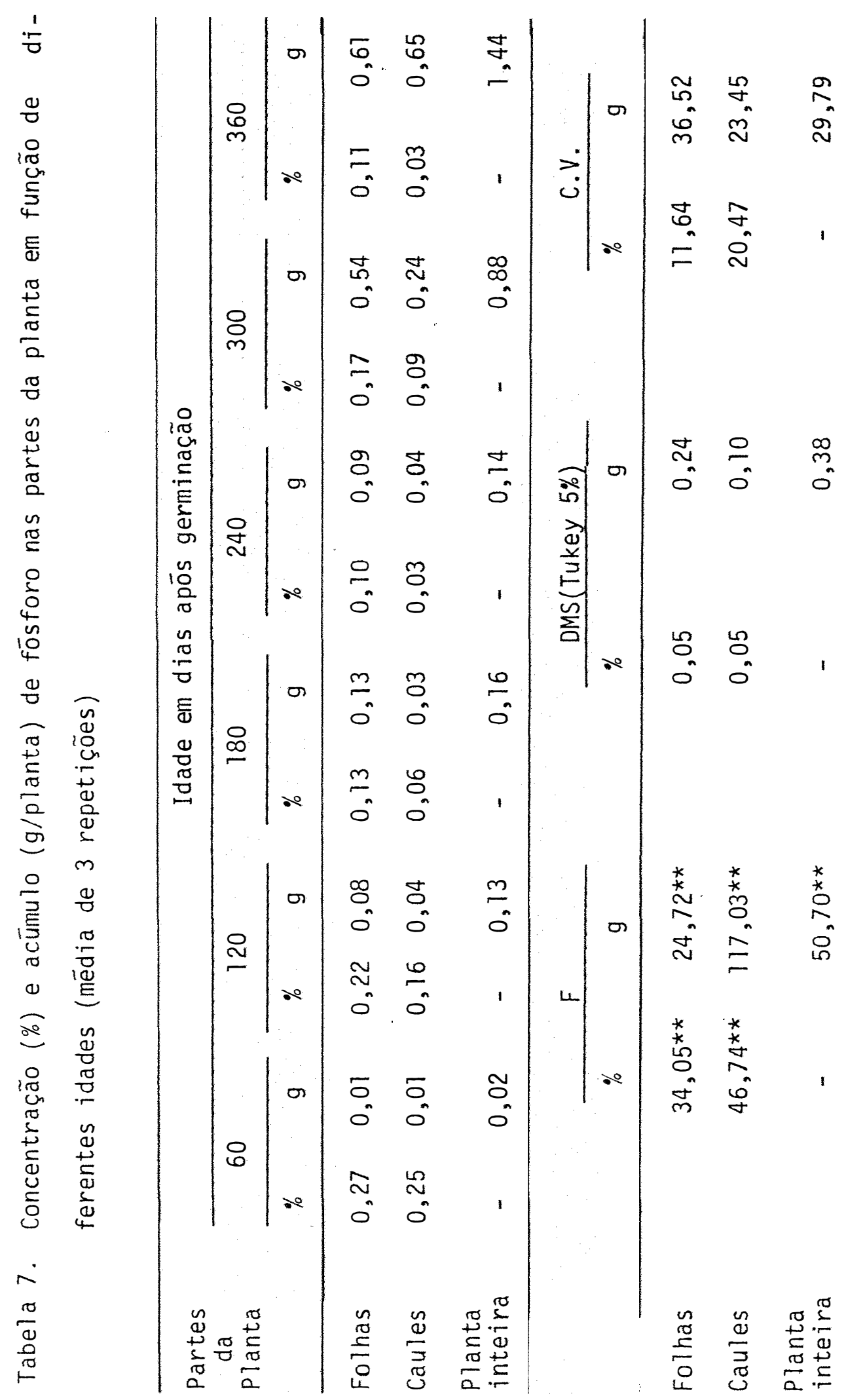




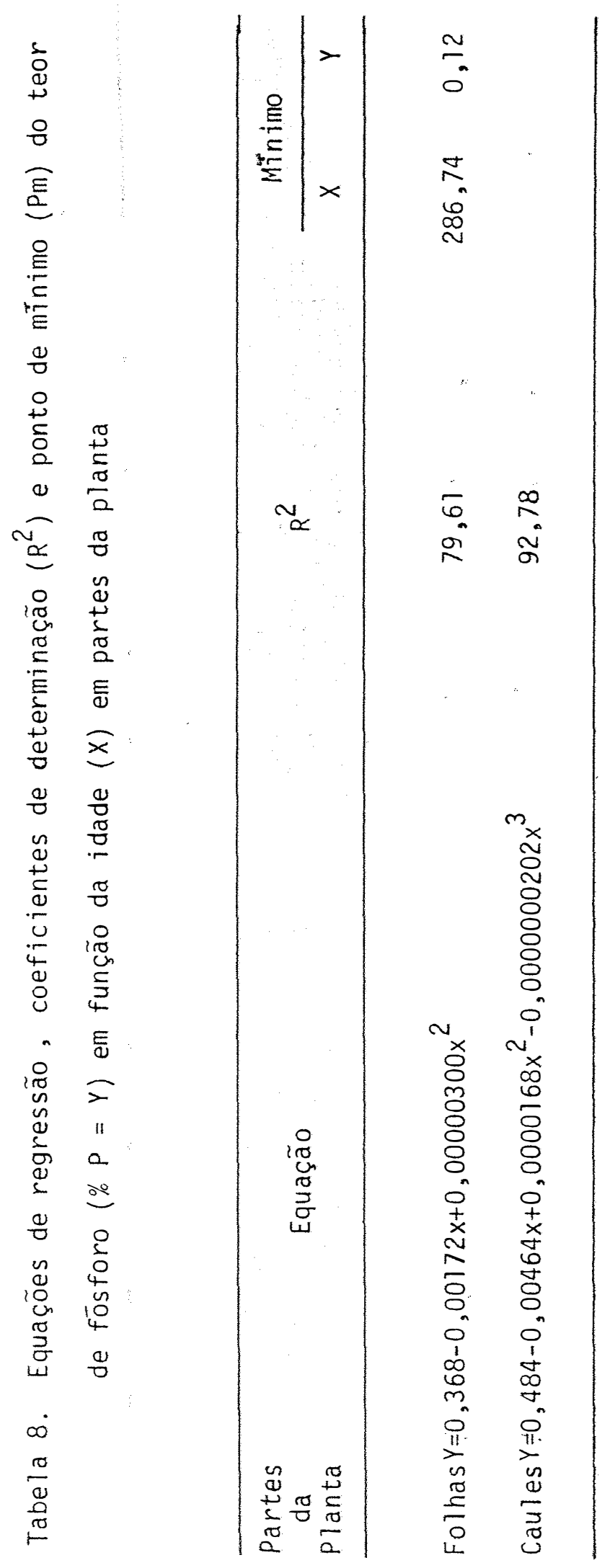


A NATIONAL ACADEMY OF SCIENCES (1976) a firma que a exigência de $P$ para o crescimento de bovinos varia de $0,18 \%$ a $0,70 \%$, valores bem acima dos encontrados para folhas de leucena. Isso leva a crer que seria possível o animal sofrer carência desse elemento caso fosse alimentado somente com folhas dessa leguminosa.

0 acúmulo de fósforo pela folha, caule e planta inteira encontra-se respectivamente nas tabelas 3,4 e 5 . Observa-se que 0 acúmulo pela folha foi 61,0 vezes maior no ūltimo corte em relação ao primeiro, no caule o aumento foi de 65,0 vezes e na planta inteira 72,0 vezes.

\subsubsection{Potássio}

as teores de potássio nas folhas e caules encontram-se na tabela 9 e mostraram correlação com a idade diminuindo segundo equações de regressão lineares presentes na tabela 10. Os teores foram bastante variáveis com o aumento da idade da planta provavelmente devido ao fato dessa leguminosa apresentar dois florescimentos ao ano. Os teores nas folhas foram em média mais altos que nos caules.

0 teor minimo observado foi de $1,99 \%$ aos 240 e 360 dias e o máximo de $3,21 \%$ aos 300 dias, dentro dessa variação está 0 valor de $2,75 \%$ de $K$ obtido por HAAG e MITIDIERI (1980) em follhas de leucena obtidas de plantas sem deficiēncia. Entretanto a NATIONAL ACADEMY OF SCIENCES (1977) relata que folhas secas de leucena podem apresentar teores que variam de $1,3 \%$ a $4,0 \%$. 


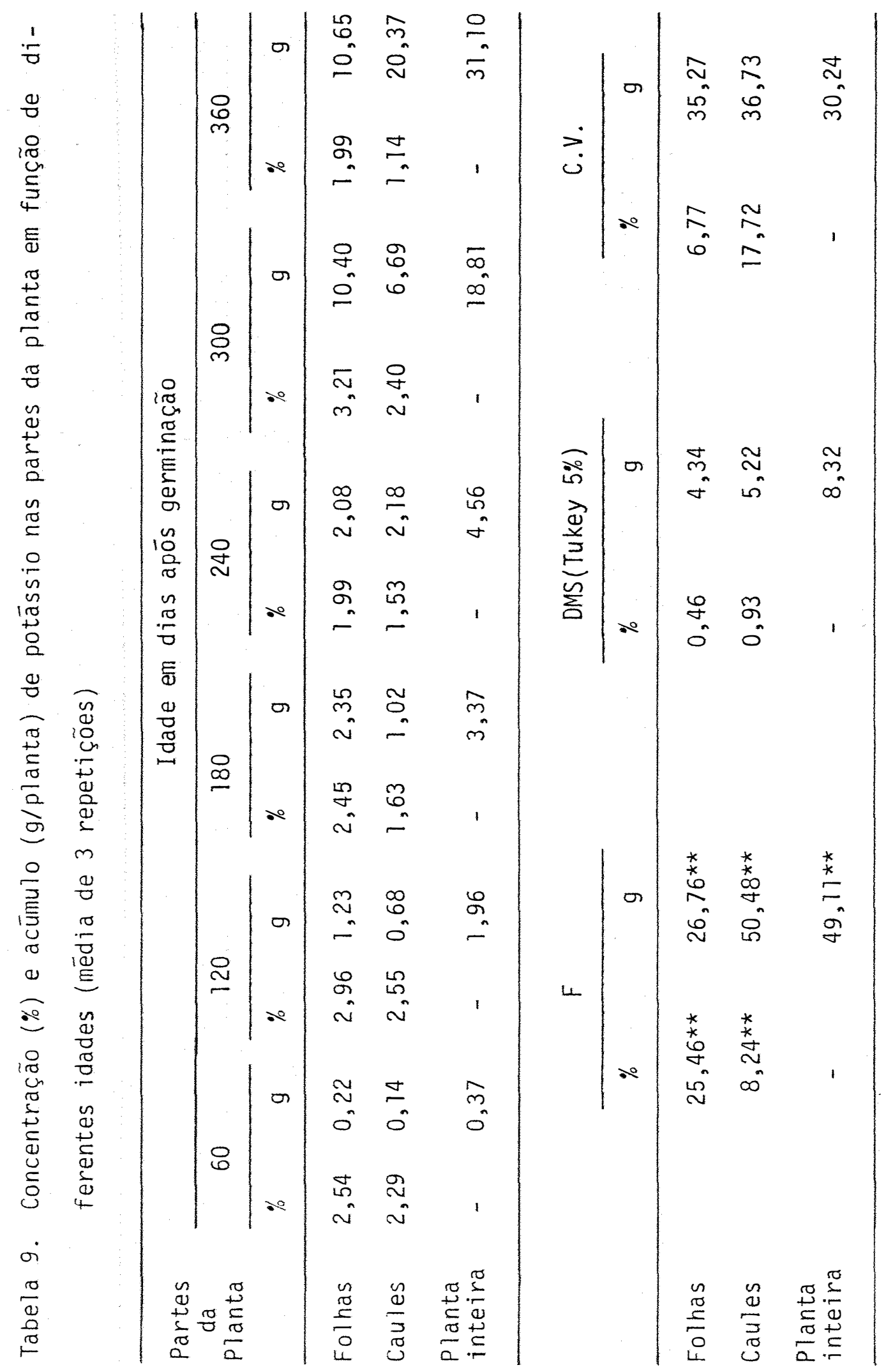




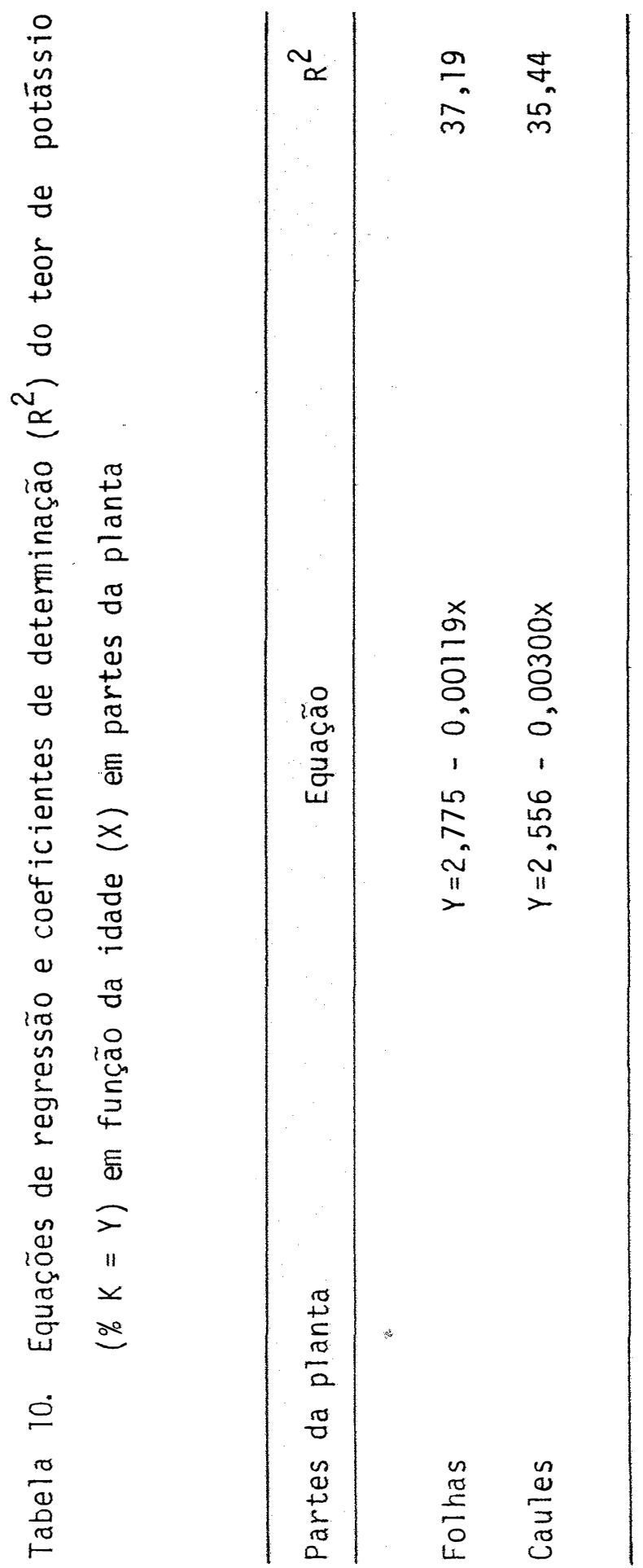


GOMIDE (1976) apresenta teores de potássio presentes em centrosema (Centrosema pubescens), siratro (Phaseollus macroptilium) e soja perene (Glycine javanica) consorciados com capim-jaraguā (Hyparhenia rufa) como sendo $1,34 \%, 1,66 \%$ e $2,06 \%$ respectivamente na matéria seca.

OLIVEIRA et alii (1978) encontraram em folhas de siratro (Macroptilium atropurpureum cv. 'siratro') teores do nutriente sempre crescente de $1,49 \%$ a $5,09 \%$ no período de 21 a 147 dias.

A NATIONAL ACADEMY OF SCIENCES (1976) afirma que a exigência de potássio para o crescimento de bovinos varia de $0,60 \%$ a $0,80 \%$, valores plenamente satisfeitos pelas folhas da planta em estudo. GALLO et alii (1974) estudando a composição de 14 gramineas e 23 leguminosas forrageiras, coletadas no Estado de São Paulo, num total de 249 amostras observaram que não houve uma sō amostra dentre todas as analisadas com teor de $K$ abaixo de $0,60 \%$, minimo adequado para bovinos. No pasto, o teor desse elemento em todas as forrageiras esteve acima de 0,80\%.

0 acúmulo de potássio pela folha, caule e planta inteira encontra-se respectivamente nas tabelas 3,4 e 5 . Observa-se que o acúmu 10 pela folha foi 48,4 vezes maior no ūltimo corte em relação ao primeiro, no caule o aumento foi de 145,5 vezes e na planta inteira 84,0 ve zes. 


\subsubsection{Cálcio}

Os teores de cālcio nas folhas e caules encontram-se na tabela 11, sendo que somente as folhas mostraram correlação com a idade traduzido por uma equação de regressão cúbica presente na tabela 12.

As folhas apresentaram um teor calculado máximo de 1,76\% aos 139 dias e um teor minnimo de $1,27 \%$ aos 297 dias, valores próximos aos observados aos 120 e 300 dias. Os dados acham-se na faixa de variação de $0,80 \%$ a 2,00\% apresentados pela NATIONAL ACADEMY OF SCIENCES (1977). Entretanto HAAG e MITIDIERI (1980) encontraram $1,11 \%$ de cálcio em folhas provenientes de plantas sem deficiência.

OLIVEIRA et alii (1978) encontraram aos 63 dias de idade para folhas de soja perene (Glycine wightii Willd.) um teor de 1,02\% de Ca e em folhas de siratro (Macroptilium atropurpureum cv. 'siratro') 1,36\% de Ca na mesma época. No presente estudo o valor observado aos 60 dias foi de $1,25 \%$ de Ca.

Para Norris, citado por GOMIDE (1976) as leguminosas tropicais são capazes de absorver cálcio do solo com grande facilidade. Tanto que o mesmo autor apresenta teores de cálcio para: capim-elefante (Pennisetum purpureum) de $0,43 \%$ aos 140 dias de idade e de $0,66 \%$ para 0 capim-pangola (Digitaria decumbens) da mesma idade. Esse mesmo autor apresenta dados de concentração de cálcio em centrosema (Centrosema pubescens), siratro (Phaseallus macroptilium) e soja perene (Glycine javanica), consorciados com capim-jaraguá (Hyparhenia rufa) como sendo $1,36 \%, 1,13 \%$ e $1,29 \%$ respectivamente na matéria seca. 


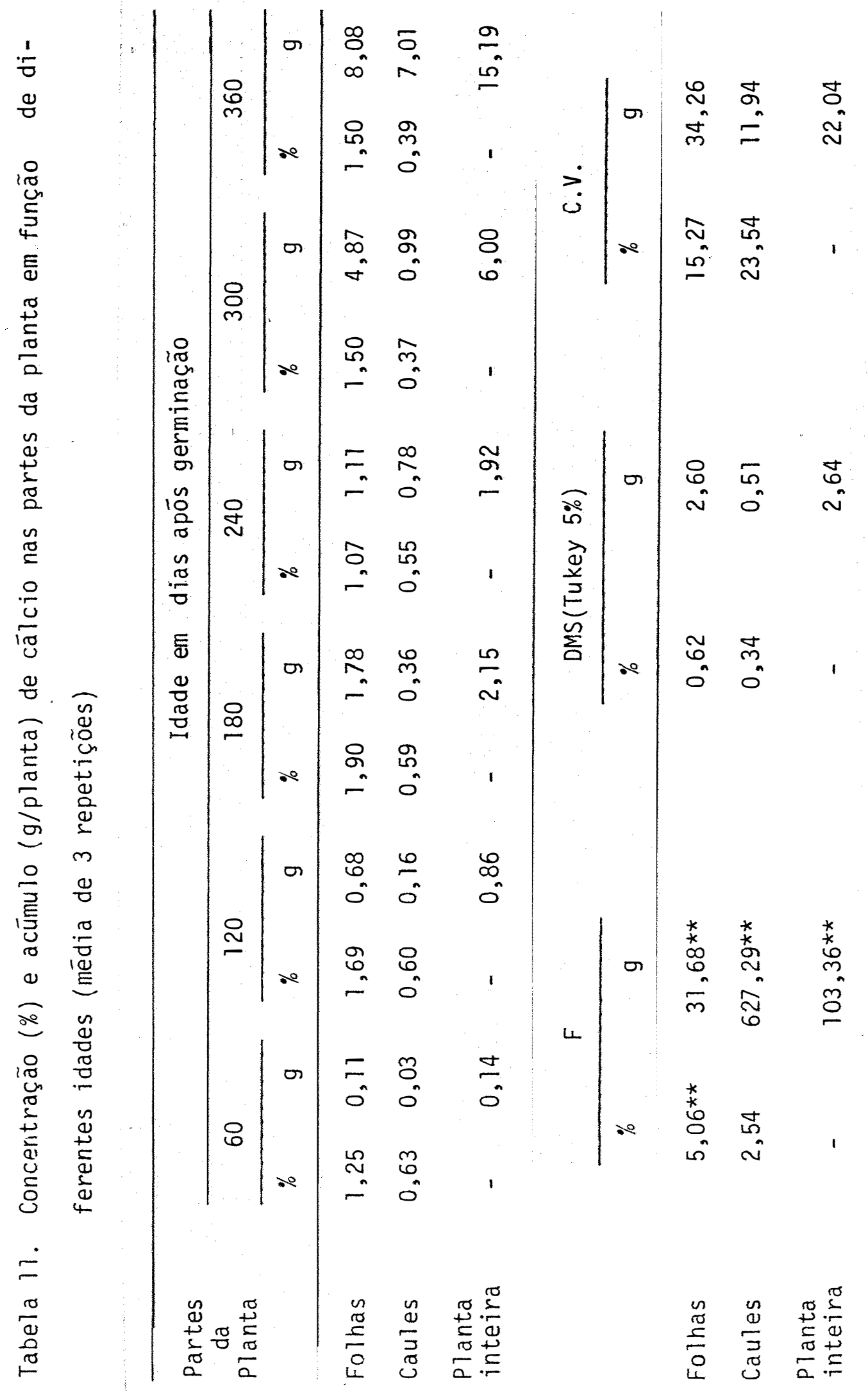



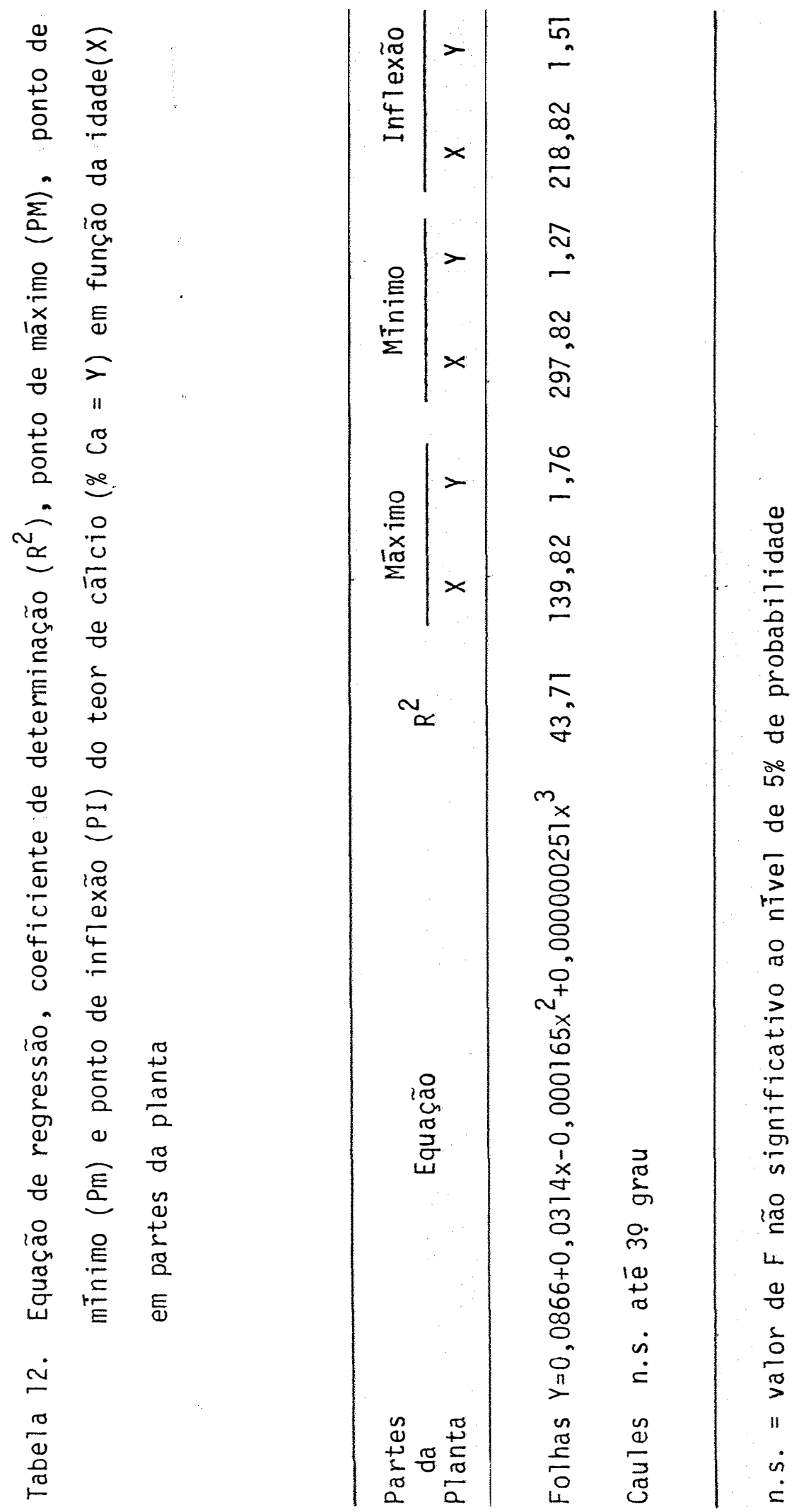
GALLO et alii (1974) estudando a composição de 23 leguminosas e 14 gramineas forrageiras num total de 249 amostras observaram que de todas as amostras analisadas $84 \%$ continham um teor de cālcio acima de $0,80 \%$.

A NATIONAL ACADEMY OF SCIENCES (1976) afirma que a exigência de cálcio para o crescimento de bovinos varia de $0,18 \%$ a $1,04 \%$, teores amplamente satisfeitos nas folhas de leucena.

0 acúmulo de cálcio pela folha, caule e planta inteira en contra-se nas tabelas 3,4 e 5 . Observa-se que o acúmulo pela folha foi de 73,4 vezes maior no ūltimo corte em relação ao primeiro, no caule o aumento foi de 233,6 vezes e na planta inteira 108,5 vezes.

\subsubsection{Magnésio}

Os teores de magnésio nas folhas e caules encontram-se na tabela 13 e mostraram correlação com a idade traduzidos por equações de regressão cúbica presentes na tabela 14 .

As folhas apresentaram um teor mäximo calculado de 0,69\% aos 293 dias e um teor minimo de $0,12 \%$ aos 115 dias. Os caules apresentaram um teor máximo de $0,25 \%$ aos 118 dias e um teor mínimo de 0,16\% aos 312 dias.

Observa-se que a concentração nas folhas variou muito pou co com a idade com exceção do valor observado aos 300 dias $(0,99 \%)$. 0 mesmo foi observado por JOHANSEN (1976) em siratro (Macroptilium 


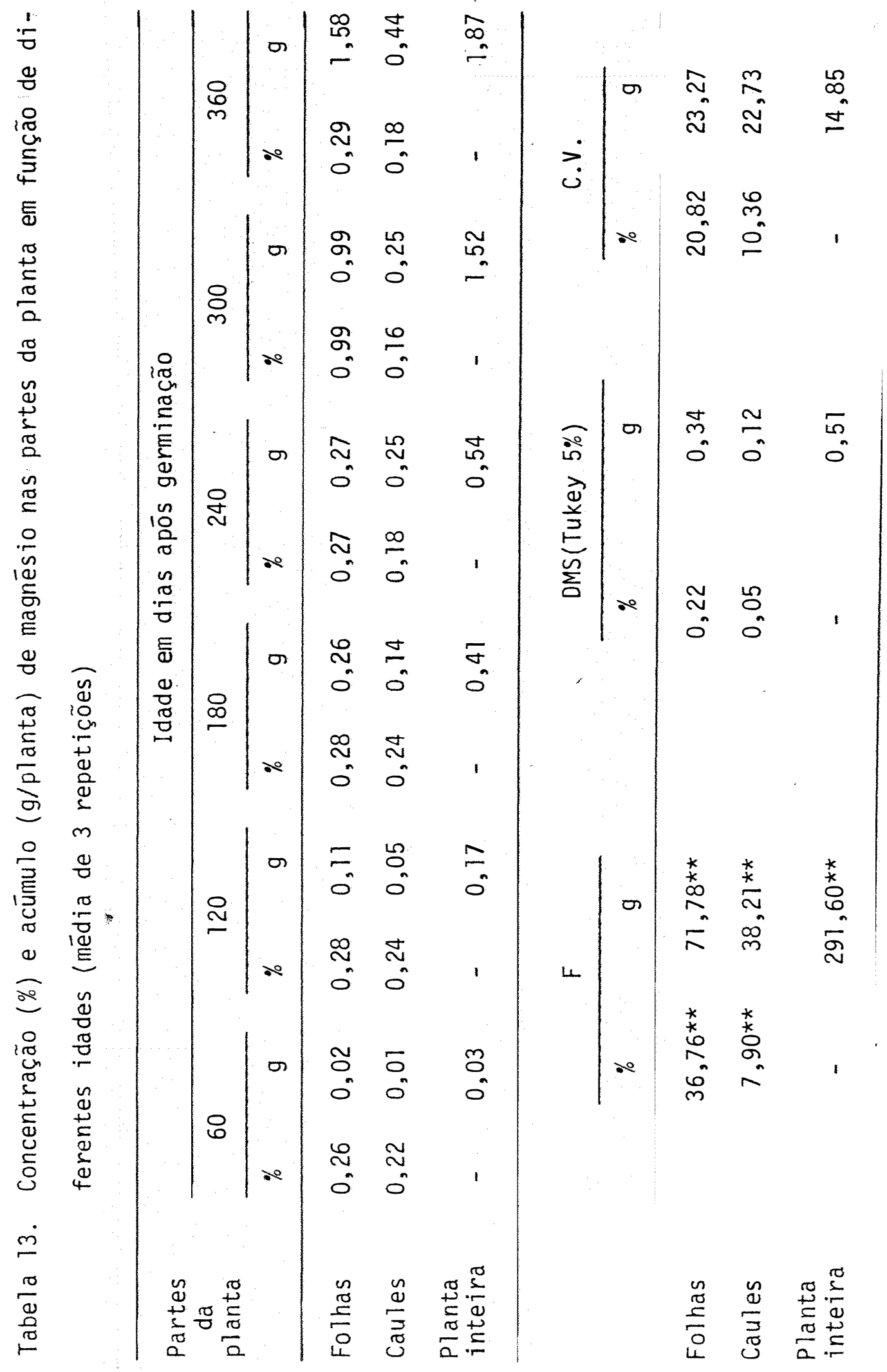




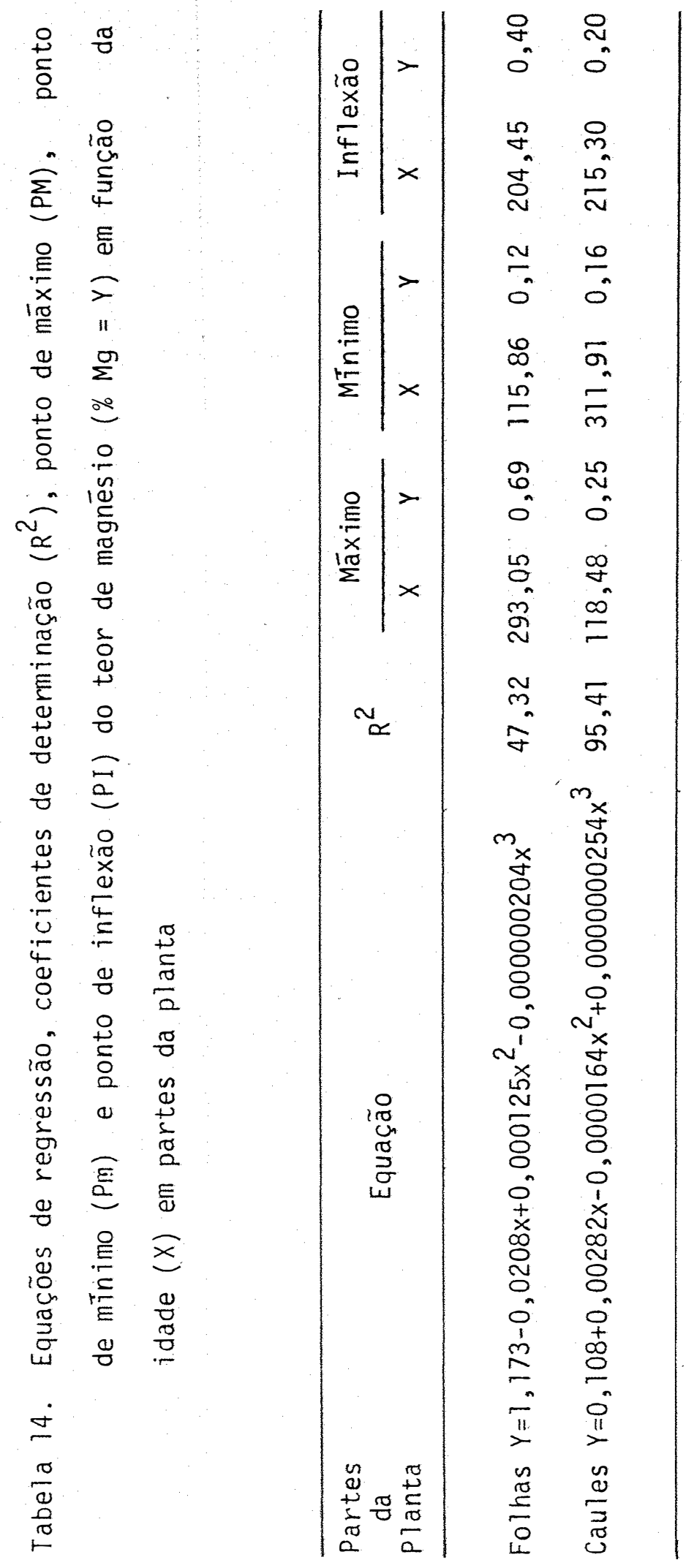


atropurpureum :cv. 'siratro') ao passo que em alfafa (Medicago sativa) e trevo (Trífolium repens) a concentração tende a aumentar com a idade da folha.

OLIVEIRA et alii (1978) encontraram aos 60 dias de idade um valor de $0,23 \%$ de magnésio em folhas de soja perene (Glycine wightii willd.) e no caule 0,20\%. No presente estudo os valores observados para as folhas foram $0,26 \%$ e para o caule $0,22 \%$ de $\mathrm{Mg}$ na mesma idade, abaixo do valor encontrado por HAAG e MITIDIERI (1980) de 0,42\% em folhas obtidas de plantas; sem deficiência.

GALLO et alii (1974) estudando a composição de 23 leguminosas e 14 gramīneas forrageiras num total de 249 amostras observaram que em $86 \%$ das leguminosas os teores de magnésio estiveram acima de 0,26\%.

$$
\text { Segundo Nelson, citado por'VIANA (1976) e GOMIDE }
$$
as leguminosas geralmente são mais ricas em magnēsio que as gramīneas.

A NATIONAL ACADEMY OF SCIENCES (1976) afirma que a exigência de magnēsio para o crescimento de bovinos varia de $0,04 \%$ a $0,10 \%$. Portanto é pouco provāvel que o animal sofra de deficiência desse elemento visto que quase não existe forragem com menos de 0,1\% (ALBA,1971),

0 acūmulo de magnésio pela folha, caule e planta inteira encontra-se nas tabelas 3, 4 e 5. Observa-se que o acúmulo pela folha foi 79,0 vezes maior no ültimo corte em relação ao primeiro, no caule o aumento foi de 44,0 vezes e na planta inteira 162,3 vezes. 


\subsubsection{Enxofre}

Os teores de enxofre nas folhas e caules encontram-se na tabela 15 e mostraram correlação com a idade segundo equações de regressão quadrātica presentes na tabela 16. Os teores nas folhas foram em mé dia maiores que os dos caules.

0 teor máximo calculado de enxofre nas folhas foi $0,27 \%$ aos 115 dias, valor bem próximo do observado aos 120 dias de idade da planta, e para o caule foi de $0,16 \%$ aos 156 dias. HAAG e MITIDIERI (1980) obtiveram 0,22\% de $S$ em folhas provenientes de plantas sem deficiēncia.

OLIVEIRA et alii (1978) obtiveram uma concentração de enxofre nas folhas de siratro (Macroptilium atropurpureum cv. 'siratro') aos 66 dias de $0,23 \%$ e no caule $0,24 \%$ na mesma idade. 0 valor calculado para folhas de leucena em plantas da mesma idade foi de 0,28\% e para os caules $0,15 \%$.

A exata quantidade de enxofre necessāria aos bovinos não è conhecida, mas tem sido estimada ser menor que $0,10 \%$ na matēria seca, assim sendo folhas de leucena poderiam supri-la satisfatoriamente.

0 acúmulo de enxofre pela folha, caule e planta inteira encontra-se respectivamente nas tabelas 3,4 e 5 . Observa-se que 0 acúmulo pela folha foi de 25,5 vezes maior no ültimo corte em relação ao primeiro, no caule o aumento foi de 151,4 vezes e na planta inteira 79,5 vezes . 


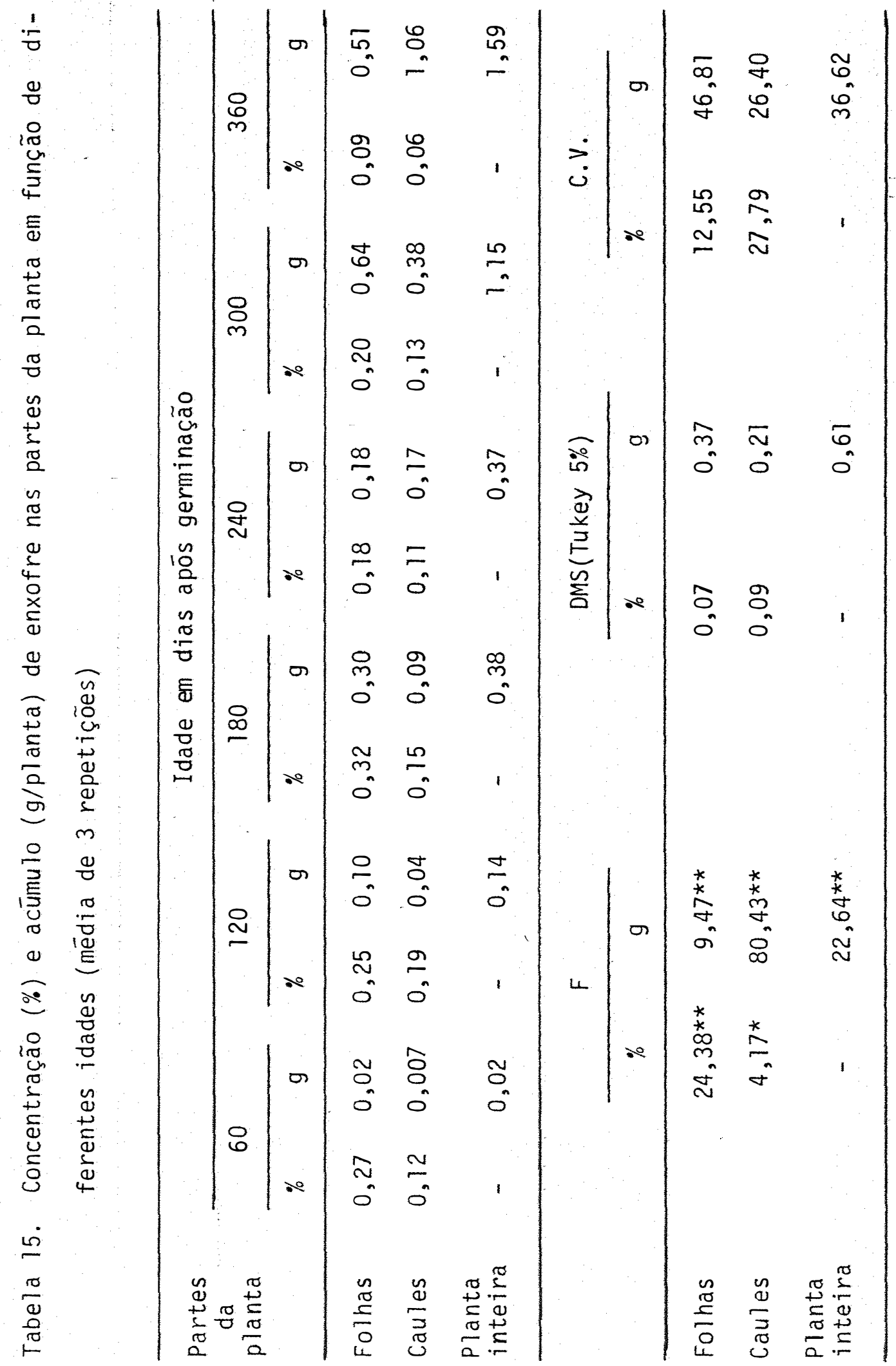


১̊

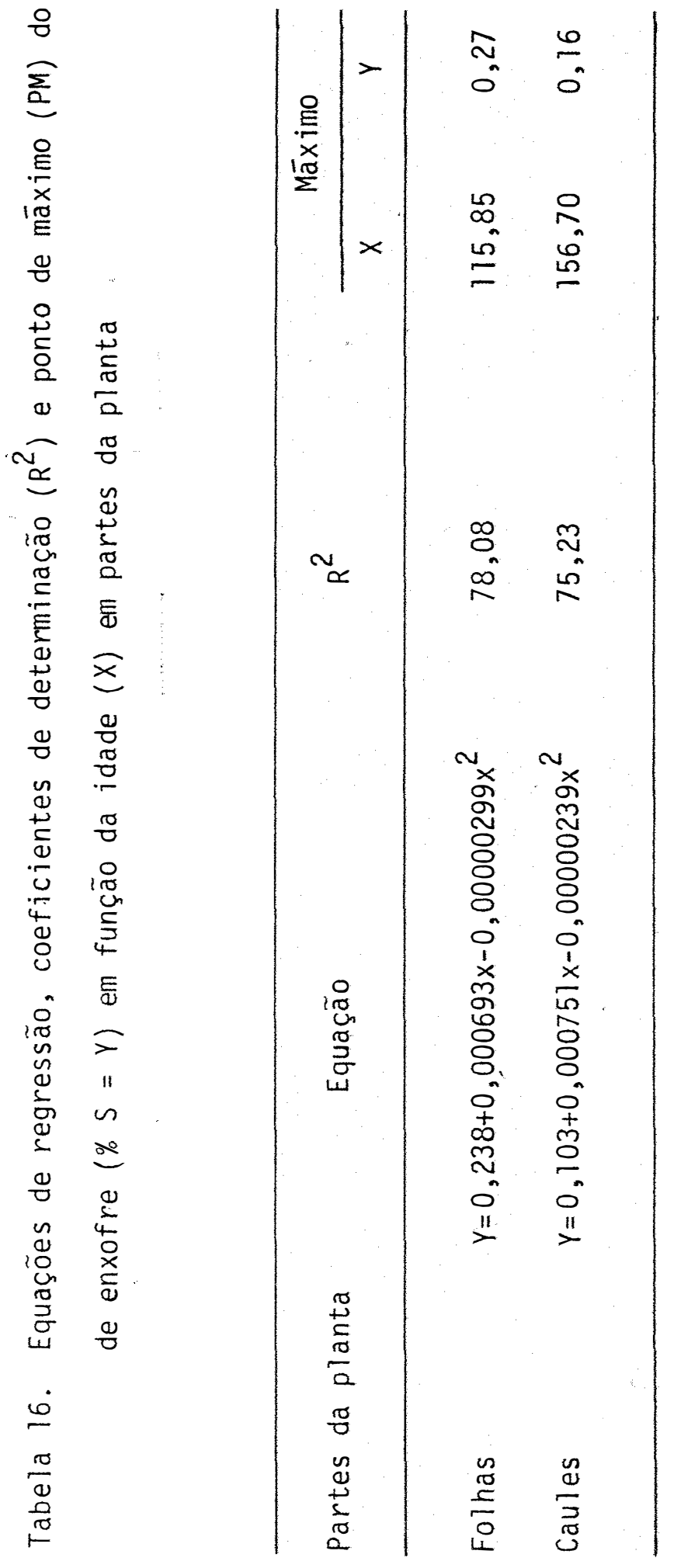




\subsection{Micronutrientes}

\subsubsection{Boro}

Os teores de boro nas folhas e caules encontram-se

na

tabela 17 e mostraram correlação com a idade, traduzido para o caule segundo uma equação de regressão quadrātica apresentada na tabela 18. Os teores nas folhas foram em média mais altos que nos caules.

A brusca diminuição na concentração de boro aos 240 dias provavelmente seja devido ao processo de formação da semente que se yerificou nesse período. O teor observado, nas folhas, mais elevado foi de 41,66 ppm aos 360 dias, bem abaixo daquele obtido por HAAG e MITIDIERI (1980) em solução nutritiva de 127 ppm em folhas provenientes de plantas sem deficiēncia.

Apesar desse elemento estar presente nos tecidos animais, não hā evidência de sua essencialidade na dieta animal (UNDERWO0D,1977). Hā evidências que leguminosas são mais ricas desse elemento que gramīneas (Benoy et alii, citado por UNDERWOOD, 1977).

0 acúmulo de boro pela folha, caule e planta inteira encontra-se respectivamente nas tabelas 3,4 e 5 . Observa-se que o acúmu10 pela folha foi 86,4 vezes maior no ūltimo corte em relação ao primeiro, no caule o aumento foi de 139,2 vezes e na planta inteira 106,4 vezes. 


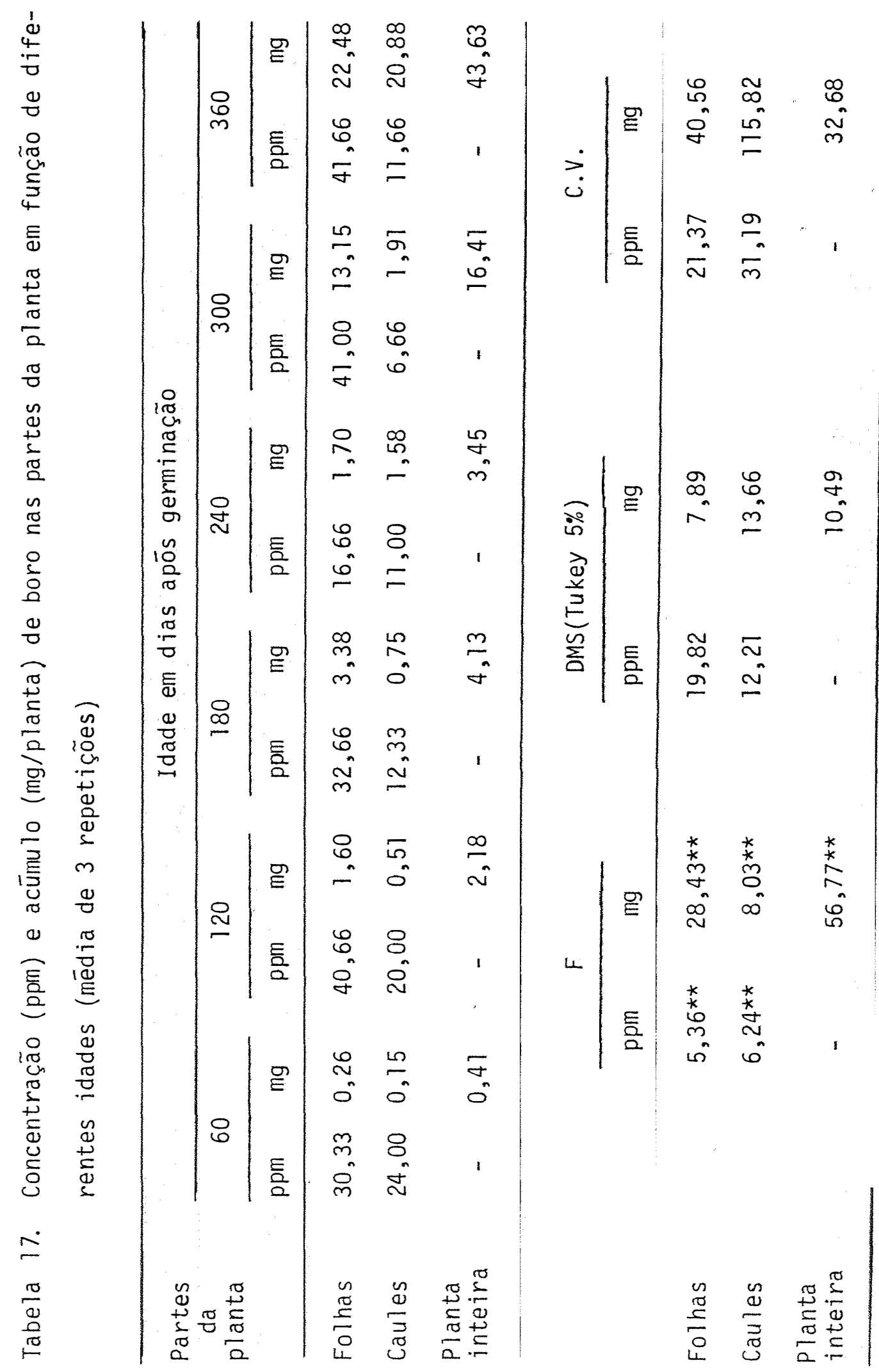


웅

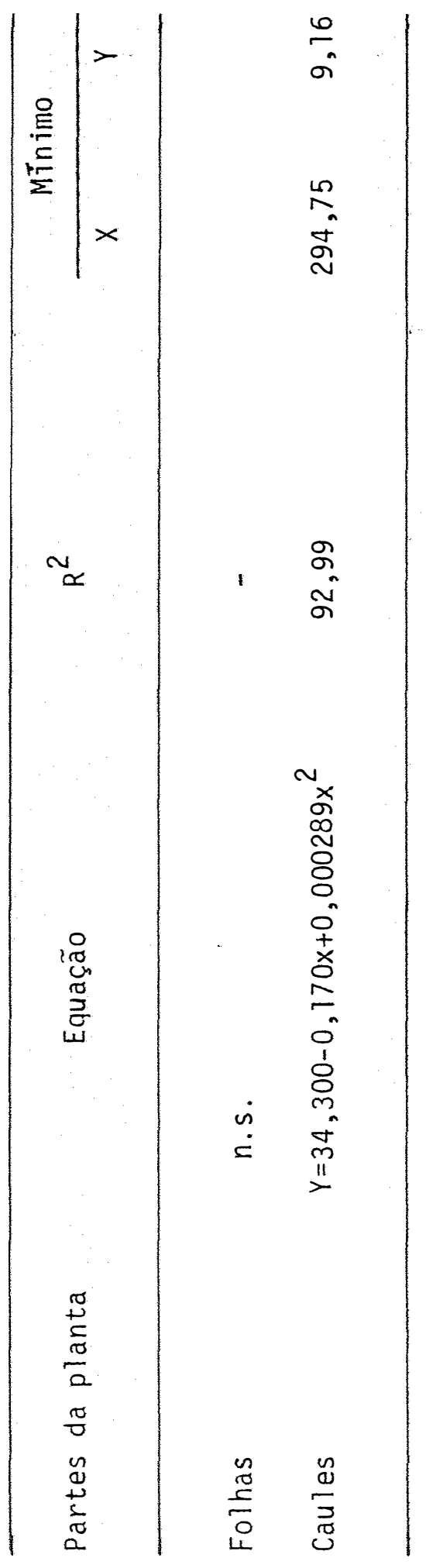




\subsubsection{Cobre}

Os teores de cobre nas folhas e caules encontram-se na tabela 19 e mostraram correlação com a idade traduzidos segundo uma equa ção de regressão quadrática e uma cūbica respectivamente, apresentadas na tabela 20. Os teores nas folhas foram consideravelmente superiores aos dos caules possivelmente devido à baixa redistribuição desse elemento.

Os teores observados nas folhas variaram de $6,33 \mathrm{ppm}$ aos 240 dias a 13,00 ppm aos 360 dias. Essa diminuição brusca da concentração de cobre aos 240 dias também pode ser atribuida à formação da semente que ocorreu nessa época. Os teores observados nos caules variaram de 1,66 ppm aos 240 dias a 7,66 ppm aos 60 dias. Pode-se dizer que as folhas de leucena são aptas à nutrição animal que exige, segundo a NATIONAL ACADEMY OF SCIENCES (1976), cerca de 4 ppm de Cu na matēria seca para o crescimento de bovinos.

ROSAS, QUINTERO e GOMES (1980) em amostras obtidas de plantas com 2,5 m de altura encontraram 4 ppm de $\mathrm{Cu}$.

0 acúmulo de cobre pela folha, caule e planta inteira encontra-se respectivamente nas tabelas 3,4 e 5 . Observa-se que o acúmu10 pela folha foi 63,4 vezes maior no ūltimo corte em relação ao primeiro, no caule o aumento foi de 362,5 vezes e na planta inteira 134,2 vezes. 


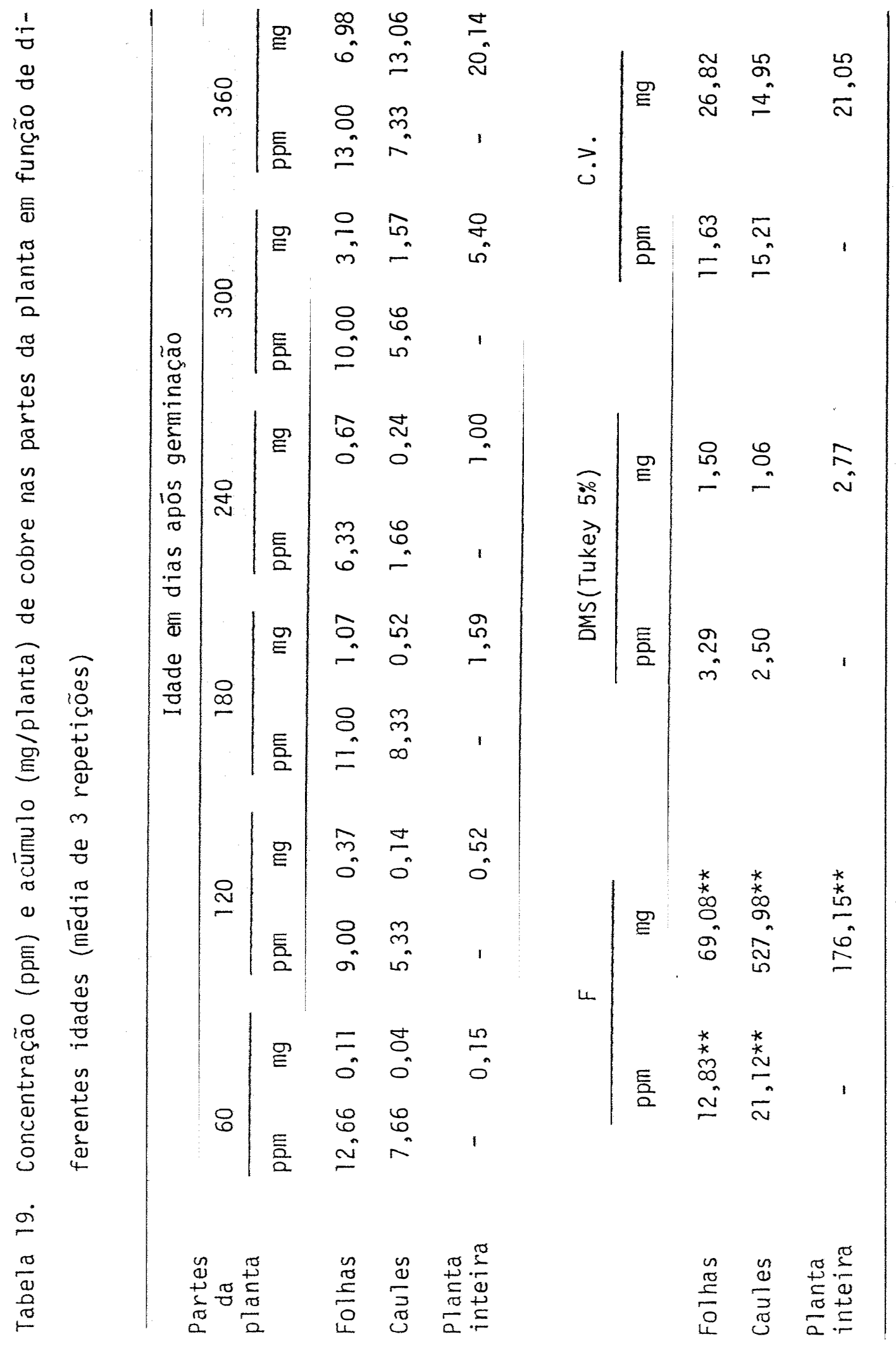



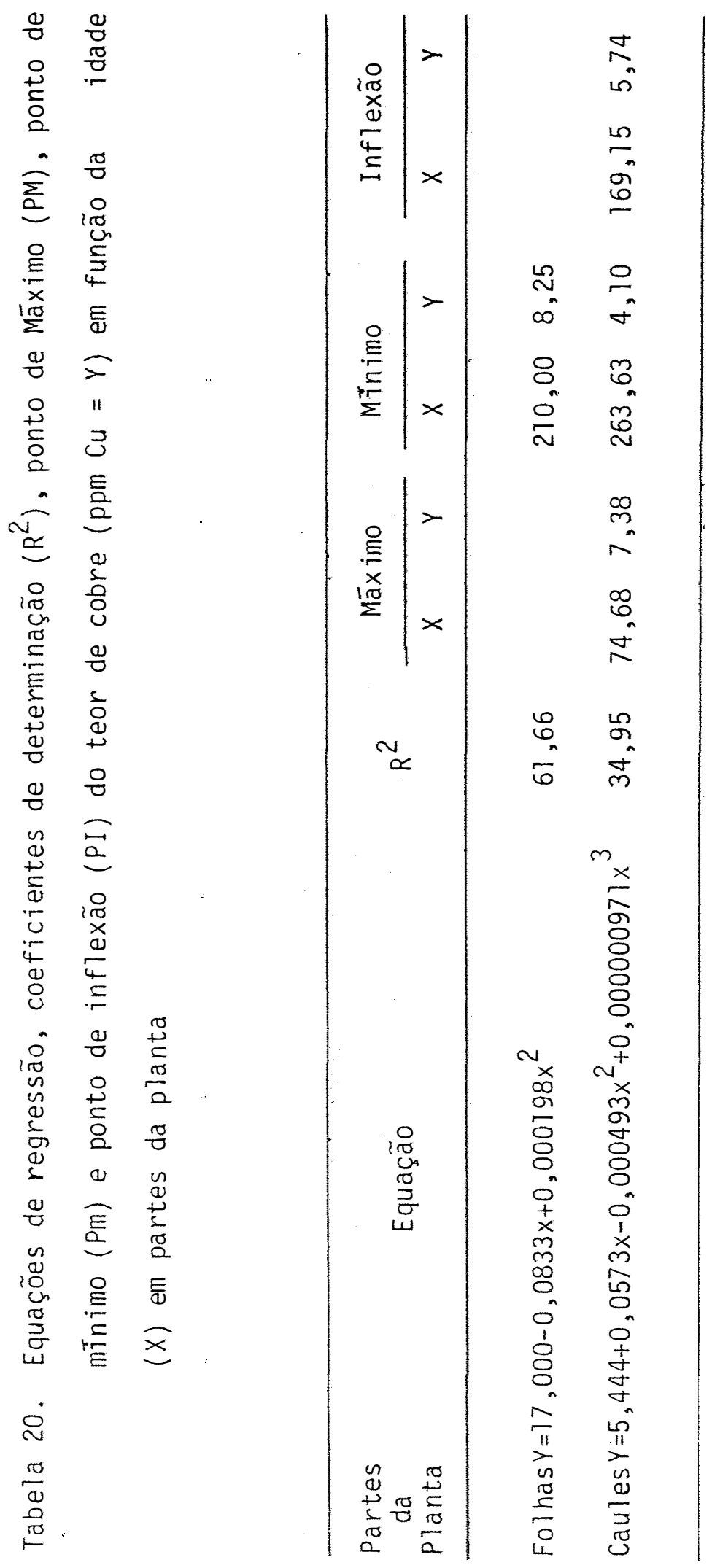


\subsubsection{Ferro}

Os teores de ferro nas folhas e caules encontram-se na tabela 21 , sendo que somente os caules mostraram correlação com a idade que foram traduzidos por uma equação de regressão quadrätica presente na tabela 22 .

Os teores nas folhas foram em média superiores aos dos caules.

A brusca diminuição na concentração de ferro aos 120 dias de idade da planta se deve provavelmente ao primeiro florescimento ocorrido nessa época, ocorrendo fato semelhante aos 360 , época do segundo florescimento. Aos 240 dias a formação da semente deve ter sido a responsävel pela queda no teor de ferro.

Segundo a NATIONAL ACADEMY OF SCIENCES (1976) a exigēncia de ferro para o crescimento de bovinos é. de 10 ppm, valor esse plenamente satisfeito pelas folhas de leucena que apresentam um valor observado de 382 ppm aos 360 dias, ëpoca de maior produção de matëria seca. GALLO et alii (1974) constataram que 96\% das 23 leguminosas estudadas no Estado de São Paulo apresentaram teores de ferro superiores a 100 ppm.

ROSAS, QUINTERO e GOMES (1980) em amostras obtidas de plantas com 2,5 m de altura encontraram 168 ppm de Fe.

0 acūmulo de ferro pela folha, caule e planta inteira encontra-se respectivamente nas tabelas 3,4 e 5.0 bserva-se que o acúmulo 


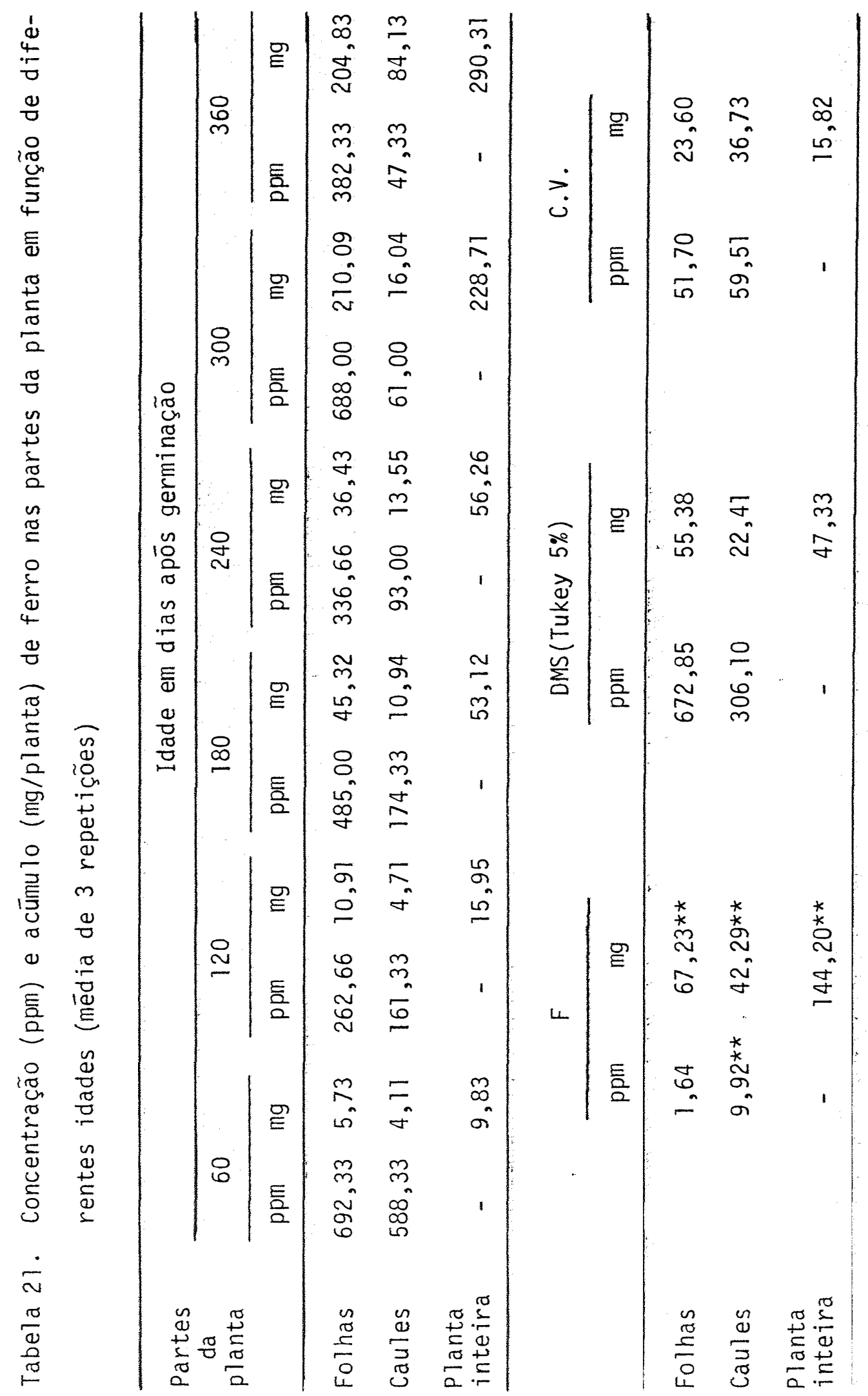




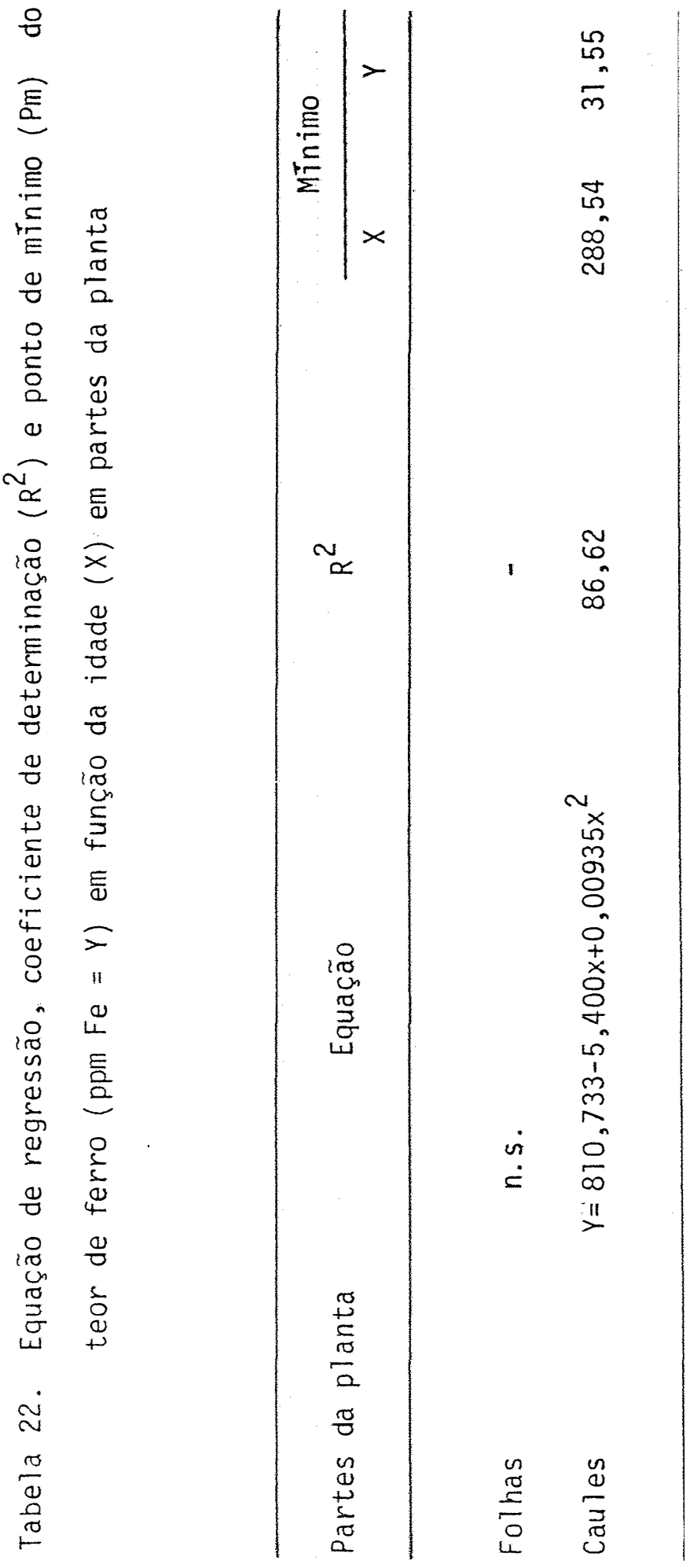


pela folha foi 35,7 vezes maior no ūltimo corte em relação ao primeiro, no caule o aumento foi de 20,5 vezes e na planta inteira 29,5 vezes.

\subsubsection{Manganès}

Os teores de manganēs nas folhas e caules encontram-se na tabela 23 e mostraram correlação com a idade, diminuindo segundo equa ções de regressão lineares apresentadas na tabela 24.

As concentrações observadas nas folhas foram considerave] mente superiores às dos caules e apresentaram pouca oscilação com o avan çar da idade,

As folhas apresentaram teores calculados de 53,49 ppm aos 60 dias a $35,75 \mathrm{ppm}$ aos 360 dias e os caules $23,35 \mathrm{ppm}$ e $3,88 \mathrm{ppm}$ respectivamente nas mesmas épocas. Portanto as folhas são suficientemente ricas em manganês para suprir a exigenncia dos bovinos que segundo a NATIONAL ACADEMY OF SCIENCES (1976) varia de 1 a 10 ppm na matéria seca.

0 acūmulo de manganês pela folha, caule e planta inteira encontra-se respectivamente nas tabelas 3,4 e 5 . Observa-se que 0 acūmulo pela folha foi 43,0 vezes maior no ūltimo corte em relação ao primeiro, no caule o aumento foi de 66,4 vezes e na planta inteira 48,5 vezes. 


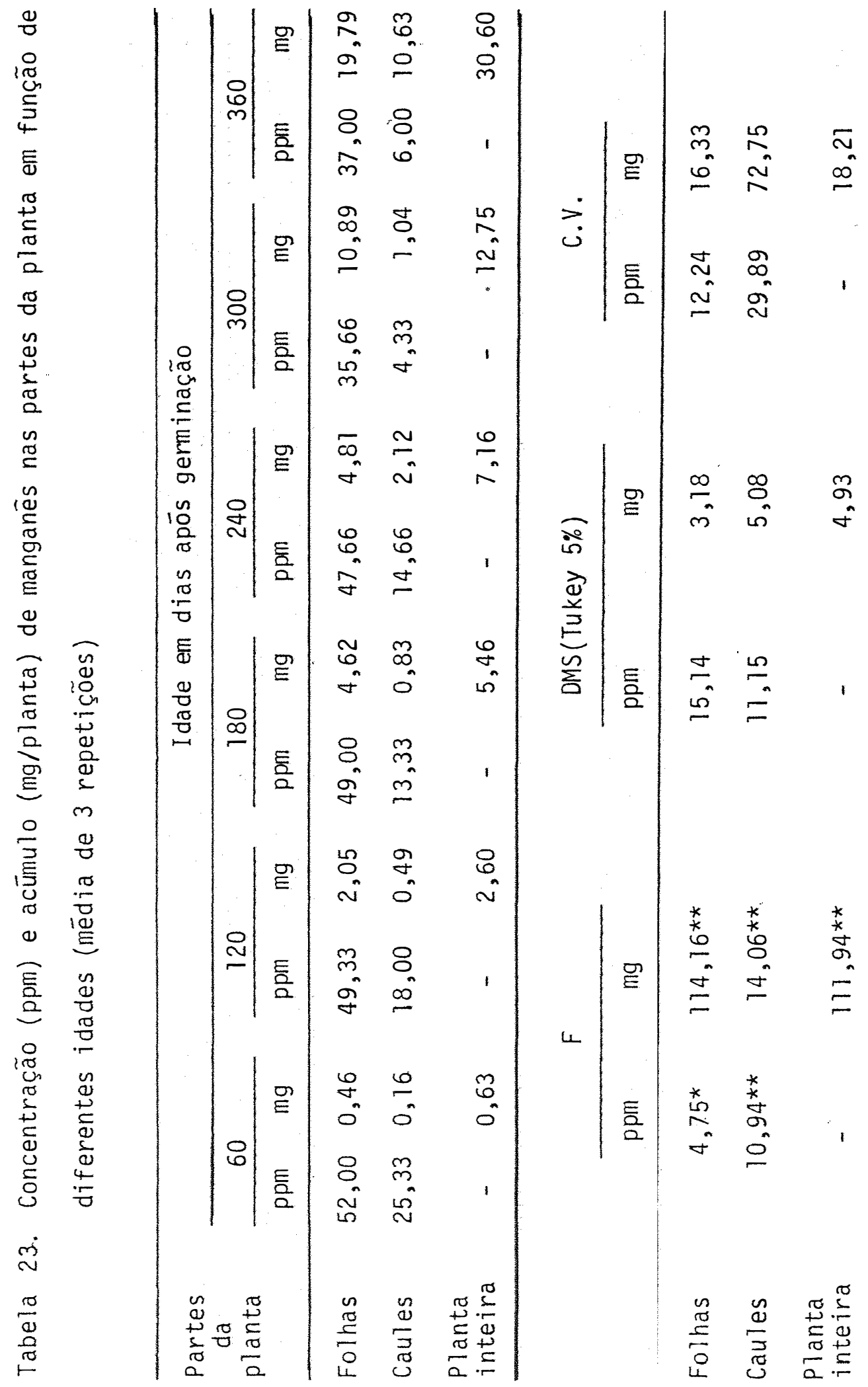




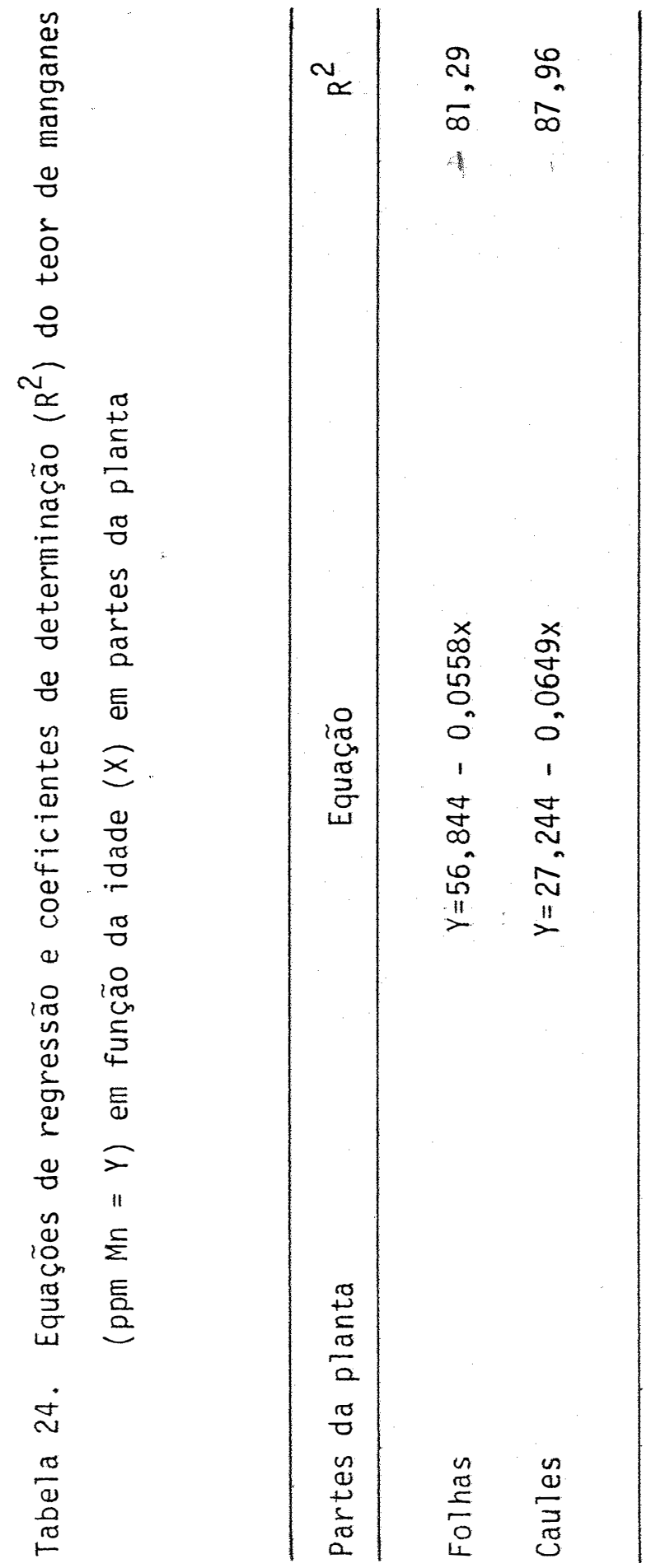




\subsubsection{Zinco}

Os teores de zinco nas folhas e caules encontram-se na tabela 25 e mostraram correlação com a idade traduzidos segundo uma equa ção de regressão cūbica e uma quadrātica apresentadas na tabela 26.

Os teores de zinco para as folhas mostraram um teor máximo calculado de $27,53 \mathrm{ppm}$ aos 92 dias e um mīnimo calculado de 14,35 ppm aos 284 dias, valores próximos dos observados.

A baixa concentração de zinco observada nas folhas aos 240 dias $(15,33$ ppm) provavelmente seja devido à formação da semente que ocorreu nessa época. E provável que o gado sofreria uma inadequação em zinco se se alimentasse exclusivamente de folhas de leucena nessa ēpoca, pois a exigência dos bovinos varia de 20 a 30 ppm na matéria seca (NATIONAL ACADEMY OF SCIENCES, 1976).

GALLO et alii (1974) estudando a composição de 14 gramīneas e 23 leguminosas, num total de 249 amostras observaram que o zinco foi o elemento que mais comumente apresentou teores abaixo das necessidades admitidas para os bovinos.

GOMIDE (1976) relata teores de zinco de centrosema (Centrosema pubescens), siratro (Phaseollus macroptilium) e soja perene (Gly cine javanica) da ordem de 40 ppm, 41 ppm e $52 \mathrm{ppm}$ respectivamente na matéria seca, valores bem acima do valor máximo calculado em folhas de leucena. 


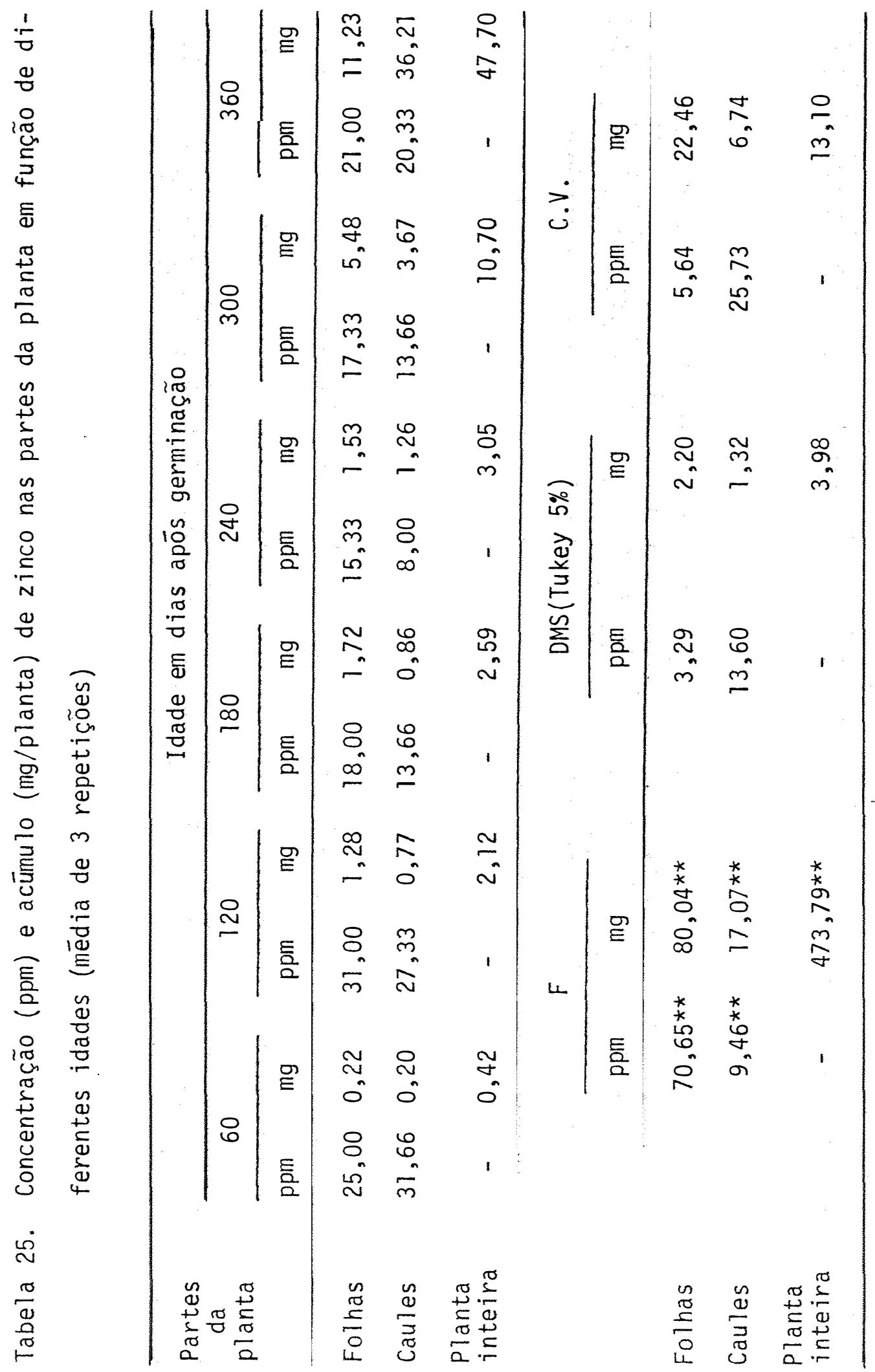




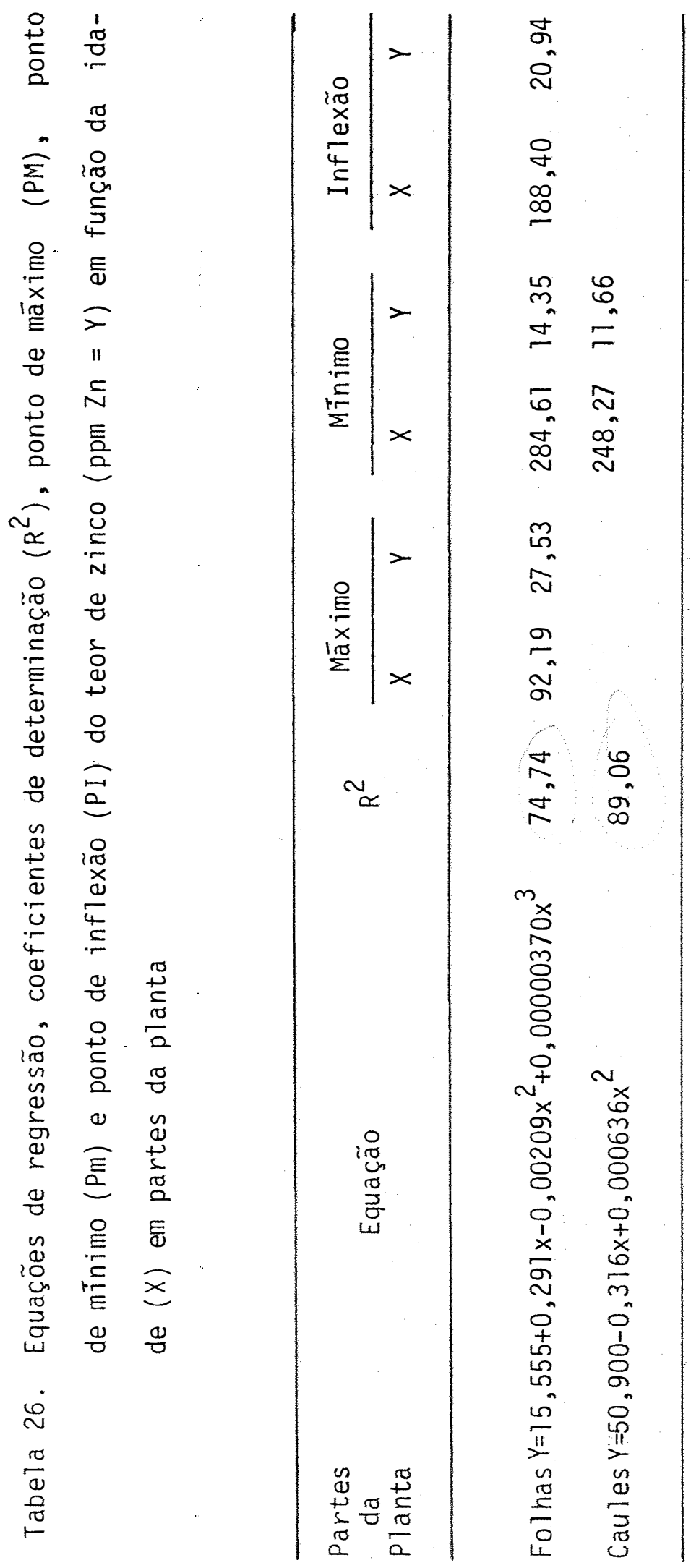


0 acúmulo de zinco pela folha, caule e planta inteira en contra-se respectivamente nas tabelas 2,3 e 4 . Observa-se que o acūmu10 pela folha foi 51,0 vezes maior no ūltimo corte em relação ao primeiro, no caule o aumento foi de 181,0 vezes e na planta inteira 113,5 vezes.

\subsection{Matéria Seca Digestîvel}

Os valores da porcentagem da matéria seca digestīvel das folhas em diferentes idades da planta acham-se expostos na tabela 27 e mostram que houve diferença significativa das épocas nos teores digestỉveis das folhas, que se adaptaram à uma equação de regressão cúbica presente na tabela 28. A digestibilidade em função da idade apresenta um valor mínimo de $61,83 \%$ aos 175 dias de idade e um máximo de 65,39\% aos 275 dias, valor este próximo daquele obtido por LIMA e SOUTO (1972) de $69,39 \%$ em feno de soja perene (Glycine wightii willd) obtido de plantas de mesma idade.

A tendēncia decrescente que apresentavam as folhas atē os 240 dias sofreu um acréscimo aos 300 dias. 0 fenōmeno é explicado pelo aparecimento de material vegetal novo logo antes do segundo florescimento aos 360 dias. 


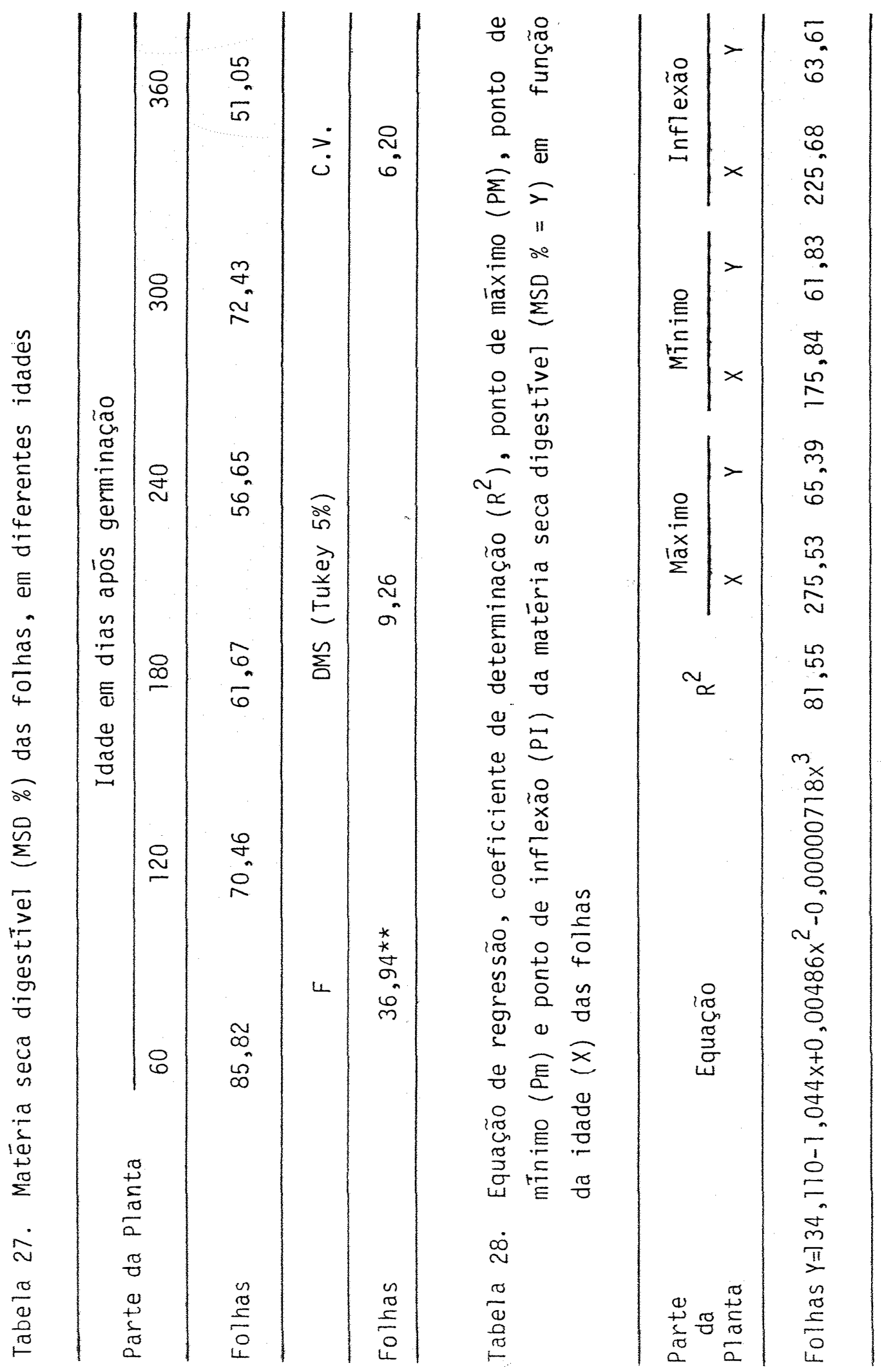


OLIVEIRA et alii (1978) encontraram para folhas de centrosema (Centrosema pubescens Benth) e siratro (Macroptilium atropurpureum cv. 'siratro') teores digestiveis crescentes com a idade. Obtiveram $44 \%$ de matéria seca digestível aos 147 dias para a primeira e $55,50 \%$ para a segunda. Tambēm encontraram para soja perene (Glycine wightii Willd) um valor de 58,81\% na mesma idade. Para a leucena o valor calculado aos 147 dias foi de $63,10 \%$.

PEIXOTO et alii (1965) pesquisando o feno de soja perene (Glycine wightii Willd) em plantas cortadas aos 90 dias de crescimento vegetativo encontraram coeficiente de digestibilidade de 75,38\% na fração matéria seca. PEIXOTO et alii (1967) encontraram 54,36\% em feno de siratro (Macroptilium atropurpureum cv. 'siratro').

0 alto teor de digestibilidade mantido até o final do experimento comprova o que foi afirmado por Siewerdt, citado por GRIPP (1970)que diz manterem as leguminosas tropicais alto teor de digestibili dade da matéria seca com o avanço da maturidade da planta. Tanto que KHARAT et alii (1980) trabalhando com plantas de leucena com um ano de idade encontraram coeficientes de digestibilidade da matéria seca varian do de $56,60 \%$ a $61,20 \%$, valores acima do observado no presente trabaTho $(51,05 \%)$. em folhas com a mesma idade. Também Upadhyay et alii, citados por JONES (1979) estudando a digestibilidade de folhas de leucena, em caprinos, observaram que a digestibilidade "in vivo" da matéria seca foi $71,4 \%$. 


\section{OBSERVAÇOEES GERAIS}

Os dados de produção de matéria seca correspondente a um hectare estão presentes na tabela 29 e foram calculados com base em 20.000 plantas por hectare. Observa-se que a produção de matéria seca é sempre crescente, salientando-se aos 360 dias um aumento substancial atribuido a lignificação do vegetal. As folhas tiveram participação maior no peso da matéria seca até os 180 dias de idade, a partir dấ até os 360 dias as posições se inverteram passando o caule a sobrepujar a folha.

Os dados de extração de macronutrientes por hectare no periodo de 360 dias estão na tabela 30. Observa-se que a leucena é capaz de acumular uma quantidade de nitrogênio máxima aos 360 dias no valor de $648,0 \mathrm{~kg}$ por hectare, que corresponde a $4050 \mathrm{~kg}$ por hectare de proteina bruta $(N \times 6,25)$. A NATIONAL ACADEMY OF SCIENCES (1977) destaca que a leucena pode produzir 800 a $4.300 \mathrm{~kg}$ de proteina por hectare. 


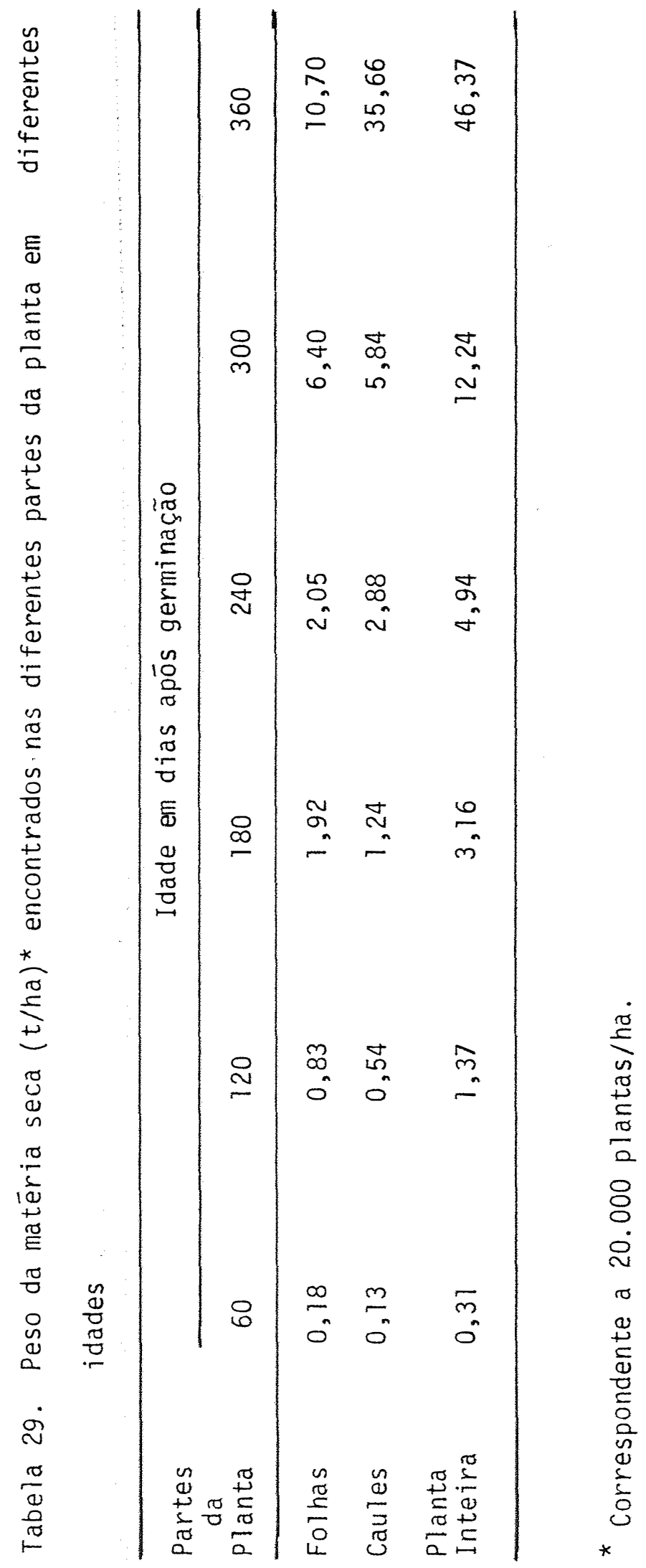




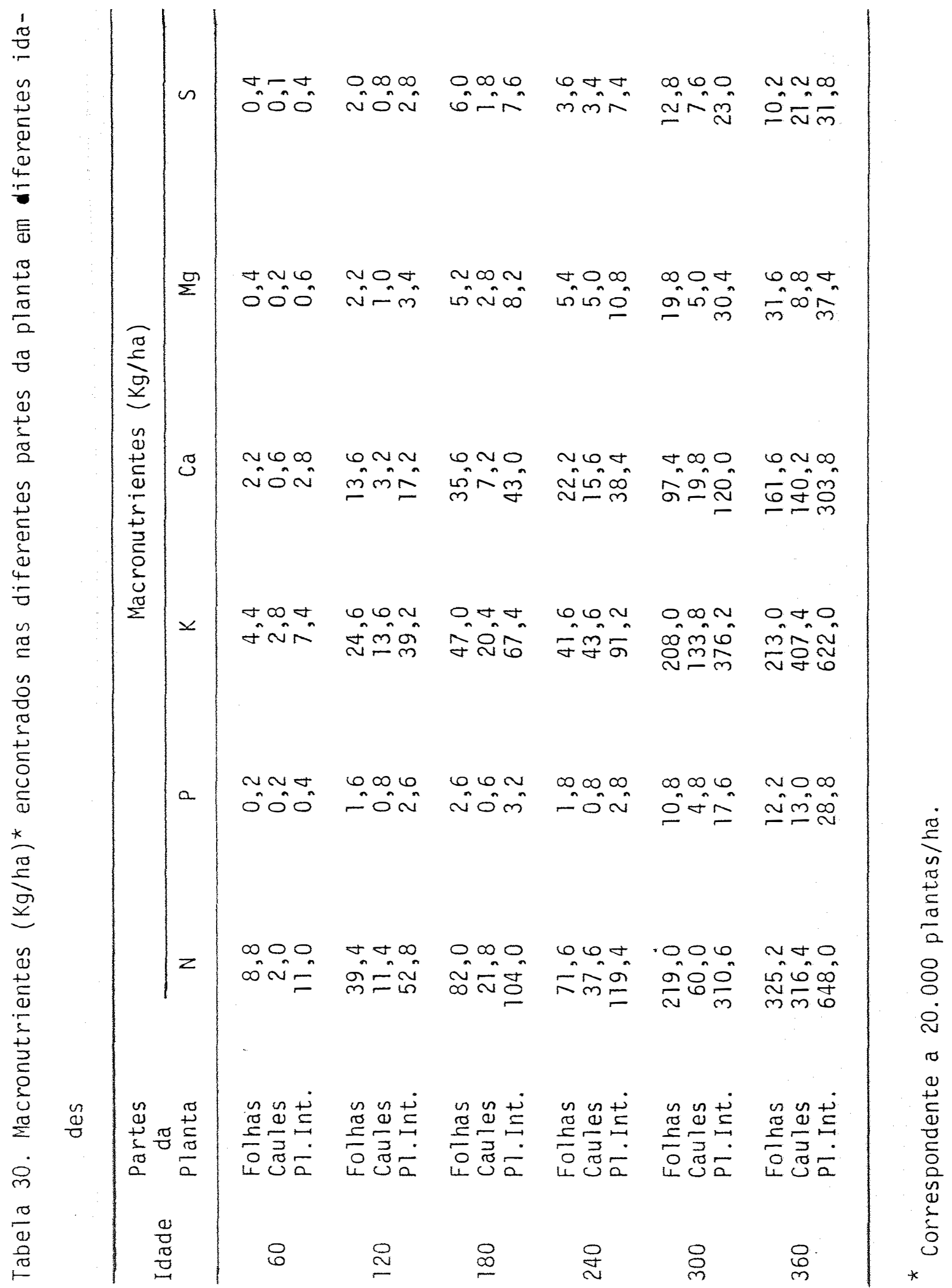


$O P \bar{e}$ acumulado em quantidades pequenas, portanto animais que se alimentam exclusivamente de forrageiras naturais ou cultivadas po dem sofrer falta desse elemento. Por teor baixo de $P$ entende-se um conteúdo menor que 0,15 de $P$ por 100 partes de matéria seca da forragem. A máxima quantidade de $P$ acumulada foi de $28,8 \mathrm{~kg} / \mathrm{ha}$ aos 360 dias para a planta inteira, valor baixo em se considerando que no Havai plantas de mesma idade continham $44 \mathrm{~kg}$ P/ha (NATIONAL ACADEMY OF SCIENCES, 1977). A maior parte das forragens que consomem os ruminantes è deficiente em fósforo, sendo portanto esse elemento usualmente um dos mais limitantes, entre os nutrientes minerais, para os ruminantes na maioria das situações.

Embora a exigência pelos bovinos de Ca e $\mathrm{P}$ sejam semelhan tes, alguns textos recomendam que a ração deve ter uma quantidade maior de Călcio, que pode ser atē uma relação $\mathrm{Ca}: \mathrm{P}$ de $2: 1$, baseado no fato que em ossos de bovinos se encontre um coeficiente de cālcio quase constante de 2:1 em relação ao fósforo. Na leucena a extração de cálcio é elevada chegando a $303,8 \mathrm{~kg}$ por hectare dos quais 161,6 acham-se nas foThas.

A exigência de potāssio para os ruminantes varia de 0,6 a $0,8 \%$, entretanto raramente se encontram forrageiras com menos de $1 \%$ na matéria seca. Dessa maneira a ocorrência de deficiência desse elemen to para ruminantes è rara, a não ser em dietas purificadas ricas em amido, motivo pelo qual sua exigência não preocupa. A leucena $\bar{e} \cdot$ rica em potāssio, apresentando aos 360 dias $622,0 \mathrm{~kg}$ por hectare. A proporção $N: P: K$ aos 360 dias é de $1: 0,04: 1$. 
0 magnēsio estā amplamente distribuido nos tecidos vegetais e animais. Aproximadamente $70 \%$ do magnésio orgānico total estā presente no esqueleto dos ruminantes em um cociente Ca:Mg de aproximadamente 55:1. Esse elemento não constitui problema para o animal em pas toreio jă que as forrageiras säo ricas desse elemento. A leucena apresenta aos 360 dias $37,4 \mathrm{~kg}$ por hectare com uma grande predominância de $31,6 \mathrm{~kg}$ nas folhas.

A quantidade exata de enxofre necessāria aos bovinos não é conhecida, mas estima-se ser menor que $0,1 \%$ na matéria seca. Portanto é dificil encontrar animais com caréncia, visto que praticamente todos os alimentos apresentam teores iguais ou superiores. A leucena apresenta $31,8 \mathrm{~kg}$ por hectare aos 360 dias. Dentre os macronutrientes esse é o elemento extraido em menor quantidade depois do fósforo.

A tabela 31 apresenta as quantidades de micronutrientes ex traidos por hectare pela leucena no período de 360 dias. A extração de boro (872,6 g por hectare) é elevada aos 360 dias, entretanto esse elemento näo é essencial aos animais.

A utilização de cobre pelos ruminantes depende em parte dos niveis de Mo e $\mathrm{SO}_{4}^{=}$. A necessidade de cobre pode aumentar até 3 vezes quando a ração contēm nîveis elevados desses elementos. A leucena possui quantidades elevadas de cobre cerca de 402,8 g por hectare aos 360 dias. 


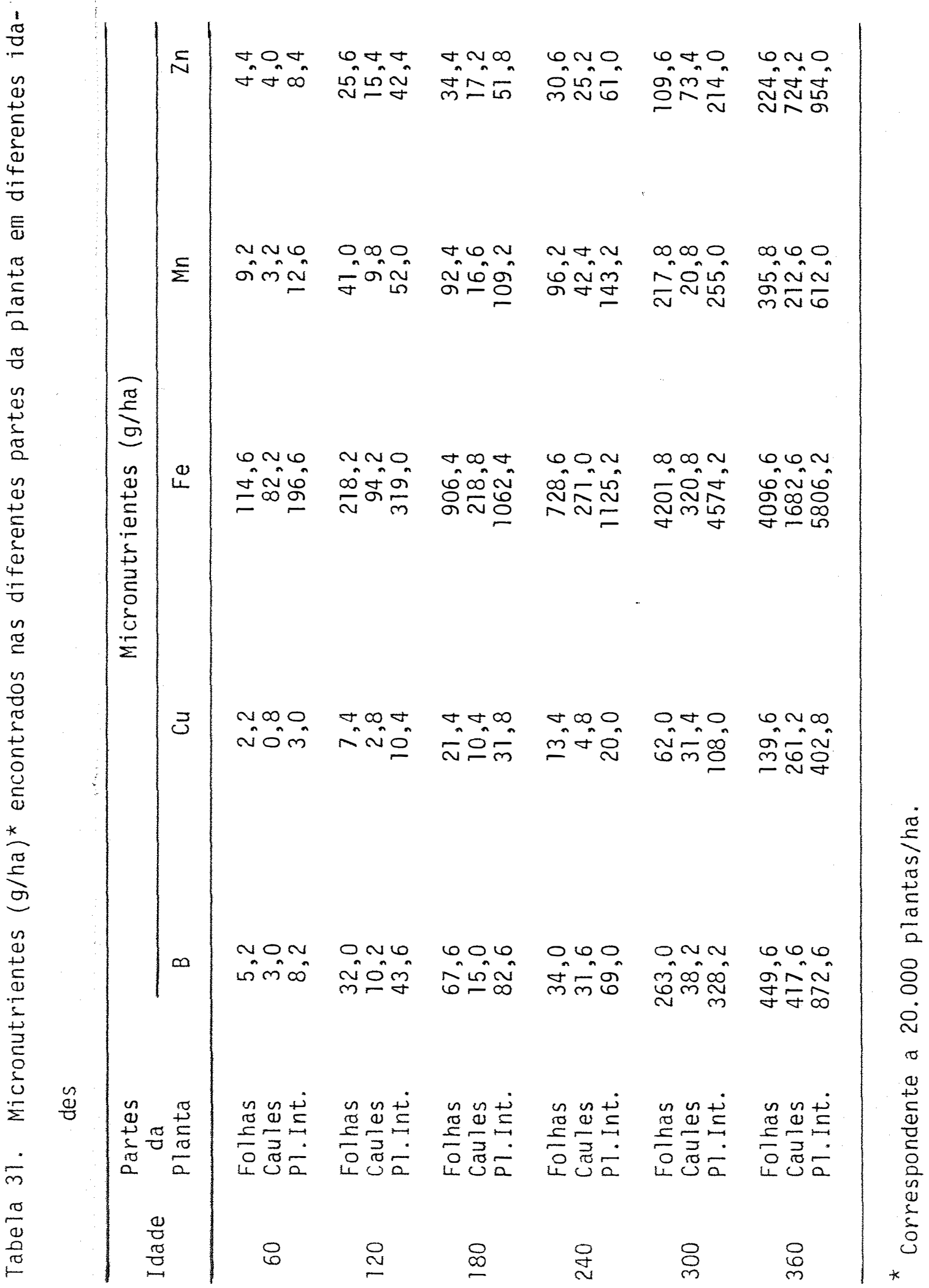


Como o ferro faz parte da hemoglobina, animais deficientes desse elemento podem apresentar anemia e retardamento do crescimento. Na prática, com raras exceções, as deficiēncias de ferro não parecem ser um problema para os ruminantes que consomem alimentos que não o leite. Um nível de $10 \mathrm{ppm}$ na matéria seca parece ser adequado. A leucena mostrou ser capaz de extrair grandes quantidades de ferro, chegando a $5.806,2 \mathrm{~g}$ por hectare aos 360 dias, estando: a grande maioria (4096,6 g) presente nas folhas.

A exigēncia de manganēs para os bovinos varia de $\quad l$ a 10 ppm na matéria seca, entretanto a maior parte das forrageiras contēm valores acima de $30 \mathrm{ppm}$. A leucena conseguiu extrair aos 360 dias $612,0 \mathrm{~g}$ por hectare, contendo as folhas $395,8 \mathrm{~g}$.

A deficiēncia de zinco provoca uma doença de nome paraqueratose, que é caracterizada por lesões na pele, atraso de crescimento e outros sintomas. O distūrbio agrava-se por excesso de cálcio na alimentação. Sua exigência ainda não estā claramente estabelecida para os bovinos, porèm há evidēncias experimentais que indicam ser necessários 20 a 30 ppm na matéria seca. A leucena acumula aos 360 dias $954,0 \mathrm{~g}$ de zinco por hectare.

Observou-se que o acúmulo de nutrientes pela leucena obedece a seguinte ordem para os macronutrientes: $\mathrm{N}>\mathrm{K}>\mathrm{Ca}>\mathrm{Mg}>\mathrm{S}>\mathrm{P}$, e para os micronutrientes $\mathrm{Fe}>\mathrm{Zn}>\mathrm{B}>\mathrm{Mn}>\mathrm{Cu}$. 
Essa leguminosa poderia ser oferecida aos animais aos 300 00 dias e alta produção $(12,24 \mathrm{t} / \mathrm{ha})$ sendo a produção somente de folhas de 6,40 t/ha. 
6. CONCLUSOES

- A produção de matéria seca total é mäxima aos 360 dias de idade da planta.

- O maior incremento na produção de folhas, expresso em matéria seca, se dá dos 240 aos 360 dias de idade da planta.

- As concentraçöes de nitrogênio, potāssio e manganês diminuem nas folhas e caules com a idade da planta.

- As concentrações de boro e ferro nas folhas não são afetadas com a idade da planta.

- A concentração de cālcio no caule não ē afetada com a idade da planta.

- As folhas aos 360 dias, ēpoca de produção māxima de matêria seca $(535,46 \mathrm{~g} / \mathrm{planta})$ contēm: 16,26 g de nitrogênio; 0,61 g de fōs foro; 10,65 g de potássio; 8,08 g de cālcio; 1,58 g de magnésio; 0,51 g de enxofre; $22 \mathrm{mg}$ de boro; $7 \mathrm{mg}$ de cobre; $204 \mathrm{mg}$ de ferro; $19 \mathrm{mg}$ de manganês e $11 \mathrm{mg}$ de zinco. 
- Os caules aos 360 dias, época de produção máxima de matéria seca $(1.783,33 \mathrm{~g} / \mathrm{planta})$ contēm: 15,82 g de nitrogēnio; 0,65 $\mathrm{g}$ de fósforo; 20,37 $\mathrm{g}$ de potāssio; 7,01 $\mathrm{g}$ de cálcio, 0,44 g de magnésio; $1,06 \mathrm{~g}$ de enxofre; $20 \mathrm{mg}$ de boro; $13 \mathrm{mg}$ de cobre; $84 \mathrm{mg}$ de ferro; $10 \mathrm{mg}$ de manganês e $36 \mathrm{mg}$ de zinco.

- 0 acúmulo de nutrientes na planta aos 360 dias obedece a seguinte ordem para os macronutrientes: $\mathrm{N}>\mathrm{K}>\mathrm{Ca}>\mathrm{Mg}>\mathrm{S}>\mathrm{P}$, e para os micronutrientes: $\mathrm{Fe}>\mathrm{Zn}>\mathrm{B}>\mathrm{Mn}>\mathrm{Cu}$.

- Aos 360 dias, a matēria seca digestīvel das folhas é de $51,05 \%$ 


\section{LITERATURA CITADA}

ADENEYE, J.A. 1981. A note on the nutrient and mineral composition of Leucaena leucocephala in Western Nigéria. Herb. Abstr., Hurley 51 (11):588

ALBA, J.de. 1971. Alimentacion del ganado en American Latina, 2 a ed. Talleres Gräficos de Editorial Fournier S.A., Mexico, 475 p.

ALCĀntARA, P.B.; V.B.G: ALCĀNTARA e O.M.A.A.GHISI. 1979. Nutrição e adubação da Leucaena leucocephala (Lam.) de Wit. Zootecnia 17(1):27-42.

ALCÂNTARA, P.B. e G.BUfARAH. 1979. Plantas forrageiras: gramineas e leguminosas. São Paulo, Editora Nobel, 150 p.

ANDREW, C.S. e D.O.NORRIS. 1961. Comparative responses to calcium of five tropical and five temperate pasture legume species. Aus.t. J. Agric. Res. 12:40-55. 
CENTRO INTERNACIONAL DE AGRICULTURA TROPICAL. 1981. Informe CIAT 1981. Cali, Colombia. $101 \mathrm{p}$.

CRAMPTON, E.W. e L.A.MAYNARD. 1938. The relation of celulose and lignin content to the nutritive value of animal feeds. J.Nutr. 15:383-395,

DAMSEAUX, J. 1957. Study of 3 leguminous forages introduced into the Belgian Congo for livestock feeding. Herb, Abstr., Hurley, 27(1):50.

D'MELLO, J.P.F. e D.THOMAS. 1978. The nutritive value of dried leucaena leaf meal from Malawi: studies with young chicks. Trop. Agr. 55(1):4550 .

FARINAS, E.C. 1953. Ipil-Ipil, the "alfafa" of the tropics - Its establishment, culture and utilization as a fooder and pasture crop. Phillip. J. Anim. Ind, Manila 12(1-4):65-84.

GALLO, J.R.; R.HIROCE; O.C.BATAGLIA; P.R.FURLANI; A.M.C.FURLANI; H.B, de MATTOS, H.J.SARTINI e M.P.FONSECA. 1974: Composição quỉmica inorgānica de forrageiras do Estado de São Paulo. B, Industr. Anim., São Pau$10 \underline{31}(1): 115-137$.

GOMIDE, J.S. 1976. Composição mineral de gramineas e leguminosas forragei ras tropicais. In: Simpósio Latino-Americano sobre pesquisa em nutrição mineral de ruminantes em pastagens. Belo Horizonte, MG. p.20-33. 
GRIPP, A. 1979. Efeito da altura e intervalo de corte na produção, teor de proteina bruta e digestibilidade "in vitro" da Galactia striata (Jacq.) Urb em solo de cerrado. Piracicaba, ESALQ-USP. (Dissertação de Mestrado).

HAAG, H.P. e J.MITIDIERI. 1980. Nutrição mineral de leguminosas tropicais. II. Carēncias nutricionais em Leucaena leucocephala (Lamb.) de Wit. Anais da E.S.A. "Luiz de Queiroz", Piracicaba, 37:71-80.

HILL, G.D. 1971. Leucaena leucocephala for pastures in the tropics. Review article. Herb. Abstr., Hurley, 41(2):111.

HUTTON, E.M. 1970. Tropical Pastures. In: Advances in Agronomy. New York. Academic Press 22:2-66.

HUTTON, E.M. 1979. Problems and sucess of legume-grass pastures "especially in tropical latim america. In: SANCHEZ, P.A. e L.E.TERGAS(ed.) Pasture production in acid soils of the tropics. Cali, Colombia, p. $81-93$.

HUTTON, E.M. e S.G.GRAY. 1959. Problems in adapting Leucaena glauca as a forage for the Australian tropics. Emp. J. Exp. Agric. 27(107): 187-196.

INSTITUTO BRASILEIRO DE GEOGRAFIA E ESTATISTICA. 1957. Enciclopédia dos Municipios Brasileiros. Rio de Janeiro. 29:297. 
ISWARAN, V.; K.S.B.SARMA e M.CONHAIRE. 1970. Soil fertility, legumes and Rhizobium efficiency. First part: introduction, effect of organic matter and soil reaction. Agric. Digest., Brussel1s, 19:1-19.

JOHANSEN, C. 1976. Concentrations of nutrient elements in parts of siratro as affected by phosphorus supply and plant age. Commun. in Soil Science and Plant Analys is $7(6): 527-545$.

JONES, M.B. e J.L.QUAGLIATO. 1970. Respostas de quatro leguminosas tro picais e da alfafa a vārios níveis de enxofre. Pesq. agropec. bras., Sér.Agron., Rio de Janeiro 5:359-363.

JONES, R.J. 1979. El valor da Leucaena leucocephala como pienso para rumiantes en los trópicos. Revista Mundial de zootecnia. Roma 31: $13-23$.

KHARAT, S.T.; V.L.PRASAD; B.N.SOBALE; A.L.JOSHI e D.V.RANGNEKAR. 1980. Note on comparative evaluation of Leucaena leucocephala, Desmanthus virgatus and Medicago sativa for cattle. Indian J. Anim. Sci. 50(8): 638-639.

LEE, B.P.K. 1981. Nutrient composition of leucaena in Taiwan. Leucaena Research Reports 2:52. 
LIMA, C.R. e S.M.SOUTO. 1972. Valor nutritivo do feno proveniente de diferentes estádios de crescimento da cultura de soja perene (Glycine javanica). Pesq. agropec. bras., Sērie Zootec., Rio de Janeiro, 7: $59-62$.

LIMA, M.M.V.; L.G.da PAZ; N.P.STAMFORD; A.G.ANDRADE; M.A.LIMA e O.V.REIS, 1981. Nodulação e fixação de nitrogénio molecular em Leucaena leucocephala cultivada em solução nutritiva. In: Anais da $18^{\mathfrak{a}}$ Reunião da Sociedade Brasileira de Zootecnia, Goiānia. p.18.

MENDOZA, R.C. e E.Q.JAVIER. 1980. Herbage yield determination from four recommended ipil-ipil (L. leucocephala) cultivars. Leucaena Newsletter. $1: 26$.

NATIONAL ACADEMY OF SCIENCES. 1976. Nutrient requirements of beef cattle, 15 a ed. Washington, D.C. $\underline{4}: 56$ p.

NATIONAL ACADEMY OF SCIENCES. 1977. Leucaena promising forage and tree. crop for the tropics. Washington, D.C., 115 p.

NEME, N.A. e L.A.C.LOVAdINI. 1967. Efeito de adubos fosfatados e calcārio na produção de forragem de soja perene (Glycine javanica L.) em "Terra de Cerrado". Bragantia. 26(28):365-379.

NORRIS, 0.0. 1965. Acid production by Rhizobium: a unifying concept. Plant and Soil. 22:143-166. 
NORRIS, D.0. 1967. The intelligent use of inoculants and lime pelliting for tropical legumes. Tropical Grasslands, 1:107-121.

OAKES, A.J. 1982. Leucaena bibliografy. Beltsville, Md., USDA, Iv.

OAKES, A.J. e 0.SKOV. 1967. Yield trials of Leucaena in the U.S. Virgin Islands. J. Agric. Univ. P. Rico. 51:176-181.

OLIVEIRA, G.D.de; H.P.HAAG; J.R.SARRUGE e M.L.V.BOSE. 1978. Nutrição mineral de leguminosas tropicais. I. Absorção de macronutrientes pela centrosema (Centrosema pubescens Benth.), siratro (Macroptilium atro purpureum cv. 'siratro') e soja perene (Glycine wightii Willd,) cultivadas em condições de campo. Anais da E.S.A."Luiz de Queiroz". 35: $341-416$.

PEIXOTO, A.M.; C.L.MORAES E A.D.PRÓSPERO. 1965. Contribuição ao estudo da composição quîmica e digestibilidade do feno de soja perene (Glycine javanica L.). In: Anais do 90 Congresso Internacional de Pastagens, São Paulo, 1:791-795.

PEIXOTO, A.M.; C.L.MORAES e M.L.V.BOSE. 1967. Contribuição ao estudo da composição quîmica e digestibilidade do feno de siratro. Anais da E.S.A. "Luiz de Queiroz". 24:229-237.

PESSANHA, M. 1956. Subsidio para o estudo do problema forrageiro no cacimbo no Planalto de Malange. Agronomia Angolana. 10:29-38. 
RANZANI, G.; 0.FREIRE e T.KINJ0. 1966. Carta de Solos do Município de Piracicaba. Piracicaba, Centro de Estudos de Solos. 85 p.

ROCHA, G.L. da; J.C.WERNER; H.B, de MATTOS e J.V.S,PEDREIRA, 1971. As 1eguminosas e as pastagens tropicais. In: DÖBEREINER, J,; P.A.da EIRA; A.A.FRANCO e A.B.CAMPELO (ed.). As leguminosas na agricultura tropical. In: Anais do Seminärio sobre Metodologia e Planejamento de Pesquisa com Leguminosas Tropicais, p.1-27.

ROSAS, H.; S.0.QUINTERO e J.GOMEZ. 1980. Nutrient evaluation of the arboreous legume leucaena in Panamā, Leucaena Newsletter 1:18,

RUSSELL, J.S. 1978. Soil factors affecting the growth of legumes on low fertility soils in the tropics and sub-tropic. In: ANDEREW, C.S, e E. J.KAMPRATH (ed.). Mineral nutrition of legumes in tropical and subtropical soils. CSIRO - Brisbane, Australia, p.75-92.

SARRUGE, J.R. e H.P.HAAG. 1974. Anälises quimicas em plantas, Piracicaba, Departamento de Quỉmica da Escola Superior de Agricultura "Luiz de Queiroz". 56 p.

SETZER, J. 1946. Contribuição para o estudo do clima do Estado de São Paulo. São Paulo, Escolas Professores Salesianos. 239 p,

TAKAHASHI, M. e J.C.RIPPERTON. 1949. Koa haole (Leucaena glauca). Its establishment, culture and utilization as a forage crop. Herb. Abste., Hurley, 20(2):68. 
UNDERWOOD, E.J. 1977. Trace elements in human and animal nutrition. 4므. ed. New York. Academic Press. 545 p.

VIANA, J.A.C. 1976. Minerais em nutrição de ruminantes: magnésio. In: Simpósio Latino-Americano sobre pesquisa em nutrição mineral de ruminantes em pastagens, Belo Horizonte, p.51-65.

VILELA, E. 1976. Efeitos de densidades de semeadura e niveis de adubação nitrogenada no estabelecimento de Leucaena leucocephala (Lam.) de Wit. Piracicaba, ESALQ-USP (Dissertação de Mestrado).

WERNER, J.C. 1977. Adubação em pastagens. In: Assistēncia Nestlē aos Produtores de Leite. 10 Encontro de Atualização em Pastagens. São Paulo, p. 43-63.

WERNER, J.C. e H.B.MATTOS. 1972. Estudos de nutrição da centrosema, Centrosema pubescens Benth. B. Industr. Anim., São Paulo, 29(2):375-391,

YE0, Y. 1977. Efeito da maturidade do capim elefante (Pennisetum purpureum, Schum), variedade napier, sobre a sua produção e o seu valor nutritivo. Piracicaba, ESALQ-USP (Dissertação de Mestrado), 